University of Wollongong

Research Online

Faculty of Arts, Social Sciences and Humanities

- Papers

Faculty of Arts, Social Sciences \& Humanities

2020

Systematic Review and Meta-Analyses: Motor Skill Interventions to Improve Fine Motor Development in Children Aged Birth to 6 Years

Karel Strooband

University of Wollongong, kfbs149@uowmail.edu.au

Marc de Rosnay

University of Wollongong, marcd@uow.edu.au

Anthony D. Okely

University of Wollongong, tokely@uow.edu.au

Sanne Veldman

Follow this and additional works at: https://ro.uow.edu.au/asshpapers

Research Online is the open access institutional repository for the University of Wollongong. For further information contact the UOW Library: research-pubs@uow.edu.au 


\title{
Systematic Review and Meta-Analyses: Motor Skill Interventions to Improve Fine Motor Development in Children Aged Birth to 6 Years
}

\author{
Abstract \\ OBJECTIVE: The objective of this study was to systematically review the evidence of motor skill \\ intervention programs on typically developing children's fine motor development aged birth to 6 years. \\ METHODS: Six electronic databases were searched with no date restrictions. Inclusion criteria were any \\ school-, community-, or home-based intervention targeting the development of fine motor skills of \\ children aged birth to 6 years; randomized controlled trials using quasiexperimental, experimental, or \\ single group prepost designs with a minimum sample size of 15 participants per group; and statistical \\ analyses of fine motor skill development at both preintervention and postintervention or addressing the \\ intervention effects on fine motor skill development. Data were extracted on design, participants, \\ intervention components, methodological quality, and efficacy. RESULTS: Twenty-five of the total 31 \\ studies reported positive intervention effects on fine motor skills. The meta-analyses included 19 studies \\ and revealed moderate effect sizes of motor skill programs on fine motor, visual motor, and manual \\ dexterity outcomes. There were substantial differences between intervention settings, facilitators, length, \\ and content with most studies implemented in school settings and facilitated by teachers. CONCLUSION: \\ Fine motor skill development in the early years is an extensive upcoming field of interest for many \\ international researchers. This review study presents evidence on the positive effects of intervention \\ programs that aim to enhance fine motor skills for young children. The findings are promising but need to \\ be interpreted with caution because of the high risk of bias in many of the studies.

\section{Publication Details} \\ Strooband, K., de Rosnay, M., Okely, A. \& Veldman, S. (2020). Systematic Review and Meta-Analyses: \\ Motor Skill Interventions to Improve Fine Motor Development in Children Aged Birth to 6 Years. Journal of \\ Developmental and Behavioral Pediatrics, 41 (4), 319-331.
}




\title{
Systematic Review and Meta-Analyses: Motor Skill Interventions to Improve Fine Motor Development in Children Aged Birth to 6 Years
}

\author{
Karel F.B. Strooband ${ }^{a}$, Marc de Rosnay ${ }^{a}$, Anthony D. Okely ${ }^{a b}$, Sanne L.C. Veldman ${ }^{c}$
}

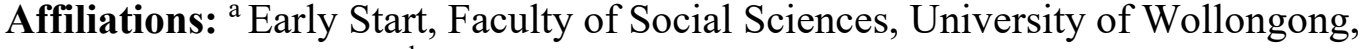
Wollongong, Australia; ${ }^{b}$ Illawarra Health and Medical Research Institute, Faculty of Science Medicine and Health, University of Wollongong, Wollongong, Australia; ${ }^{\mathrm{c}}$ Department of Public and Occupational Health, Amsterdam Public Health Research Institute, Amsterdam University Medical Center, Amsterdam UMC, Vrije Universiteit Amsterdam, Amsterdam, The Netherlands

\begin{abstract}
Objective: The objective of this study was to systematically review the evidence of motor skill intervention programs on typically developing children's fine motor development aged birth to six years.

Methods: Six electronic databases were searched with no date restrictions. Inclusion criteria were any school-, community- or home-based intervention targeting the development of fine motor skills of children aged birth to six years; randomized controlled trails (RCT) using quasi-experimental, experimental or single group pre-post designs with a minimum sample size of 15 participants per group; and statistical analyses of fine motor skill development at both pre- and post-intervention or addressing the intervention effects on fine motor skill development. Data were extracted on design, participants, intervention components, methodological quality and efficacy.

Results: Twenty-five of the total 31 studies reported positive intervention effects on fine motor skills. The meta-analyses included 19 studies and revealed moderate effect sizes of motor skill programs on fine motor, visual motor and manual dexterity outcomes. There were substantial differences between intervention settings, facilitators, length and content with most studies implemented in school settings and facilitated by teachers.

Conclusion: Fine motor skill development in the early years is an extensive upcoming field of interest for many international researchers. This review paper presents evidence on the positive effects of intervention programs that aim to enhance fine motor skills for young children. The findings are promising, but need to be interpreted with caution due to the high risk of bias in many of the studies.
\end{abstract}




\section{INTRODUCTION}

Fine motor skills form the foundation of many day-to-day activities in the early stages of life, such as eating, drawing and dressing. They are also essential for successful transition to formal schooling. The Australian Early Years Learning Framework ${ }^{1}$ and the Head Start Early Learning Outcomes Framework ${ }^{2}$ identify the importance of fine motor development as a foundation for children's independence. Yet, various studies reveal that a large proportion $(10 \%$ to $24 \%)$ of young children experience difficulties performing fine motor skills adequately. ${ }^{3-6}$ To support children's fine motor skill development effectively, more research is needed to explore the efficacy of intervention methodologies that aim to improve fine motor skills at an early age.

Fine motor skills involve smaller muscle movements to hold and manipulate small objects with the use of hands and fingers, which typically also requires eye-hand coordination. ${ }^{7}$ In the extant literature, several terms are closely linked with fine motor skills, including: visual motor skills, visual motor integration, manual dexterity, perceptual motor skills, and graphomotor skills. Minor functional discrepancies can be made between these different terms. For example, visual motor skills require the ability to respond to a visual impulse with the correct fine motor action, ${ }^{8}$ whereas manual dexterity involves the coordination and manipulation of objects through the use of fine motor movements in a timely manner. ${ }^{9}$ Despite these differences in defining specific fine motor behaviors, such differences have generally been the focus of research that examines specific skill development. At this time, however, there is not a clear basis in the literature to focus exclusively on a narrow range of fine motor skills or a specific fine motor skill function in the context of young children's fine motor skill development and, therefore, the current paper employs a broad definition of fine motor skills that incorporates these existing specific definitions.

There is a robust literature that documents associations between fine motor skills and a range of important learning and developmental domains, such as children's gross motor skills, ${ }^{10-12}$ school achievement ${ }^{7,12-18}$ and aspects of their executive functions. ${ }^{10-13,19}$ For example, it has been suggested that more advanced fine motor skills in preschoolers predicts higher reading and mathematics levels in the initial years of primary school. ${ }^{14,15}$ Therefore, understanding children's fine motor skills and supporting its development in the early years is likely to be an important aspect of children's preparedness for future learning and school achievement. Despite the apparent importance of fine motor skills in early childhood, the current literature indicates that a relatively high proportion of young children are delayed (10\% to $24 \%)$ or at risk (an additional 13\% to $40 \%$ ) of fine motor skills delay. ${ }^{3-6}$ Therefore, methods to promote fine motor skill development need to be examined and validated.

In light of these facts, preschool education may be an appropriate and reliable setting in which to tackle delay of fine motor skill development at an early age. A high proportion of children are enrolled at preschool from an early age, and there is already recognition that fine motor skill development should be a focus of daily preschool activities. ${ }^{1,20,21}$ Worldwide, almost $50 \%$ of children are enrolled at preschool before an age of 5 years, with $77.6 \%$ at an age of 3 and 4 years. ${ }^{20}$ Furthermore, in Head Start classrooms within the US, for example, 4year-olds spent approximately $37 \%$ of their time performing fine motor activities and in kindergarten this increased to $46 \%{ }^{21}$ The fine motor activities within these Head Start classrooms were mainly ( $35 \%$ out of $37 \%$ ) devoted to non-academic content, including finger play, art activities, eating, manipulative play (e.g. playdough), play in centers (e.g. block play), hygiene task, and putting on and taking off coats. ${ }^{21}$ Although more than one third of time in an education setting being devoted to fine motor activities, there are still a large 
proportion of children exhibiting fine motor skill deficits and these need to be addressed appropriately. While intervention effects on fundamental movement skills (i.e. gross motor skills) have been closely investigated ${ }^{22-24}$ and have led to improved guidelines and practices, less attention has been given to intervention effects on fine motor skill development. A systematic review by Case and colleagues ${ }^{25}$ examined the effects of occupational therapy on both gross and fine motor performance in children between birth and six years. In this review, limited data were available on the effects on fine motor skill development among children with motor delay, with only four of 24 studies reporting on fine motor skill outcomes. ${ }^{25}$

To our knowledge, the efficacy of motor skill intervention programs on fine motor skills in typically developing children has not been evaluated. A defined literature review is important to identify current effective methods that promote fine motor skills and provide recommendations for future fine motor research in the early years. Therefore, the purpose of this systematic review and meta-analyses was to describe and evaluate the efficacy of motor skill intervention programs on fine motor skill outcomes in typically developing children aged birth to six years.

\section{METHODS}

This review and meta-analyses was reported in accordance with the Preferred Reporting Items for Systematic Reviews and Meta-analyses (PRISMA) Statement. ${ }^{26}$ Eligibility Criteria

Types of studies. Randomized controlled trails (RCT) using quasi-experimental, experimental or single group pre-post designs were included with a minimum sample size of 15 participants per group. Studies were excluded if: (1) participants were children with physical, mental, language, intellectual or developmental disorders/delays (e.g. apraxia, cerebral palsy, autism) (2) participants were born preterm (i.e. $<37$ weeks); (3) articles were not peer-reviewed or no full text was available; and (4) the research was not published in English.

Types of participants. Studies that targeted children aged between birth and six years for at least one timepoint of assessment. Children were typically developing and generally healthy irrespective of fine motor skill level, weight status, living areas and/or socioeconomic status.

Types of interventions. Any motor skill interventions implemented in preschools, primary school, community services or at home aimed at improving fine motor skill development in children.

Types of outcome measures. Studies reporting statistical analyses of fine motor skill development at both pre- and post-intervention or addressing the intervention effects on fine motor skill development were included. Studies must have used a validated tool which assessed at least one of the related fine motor skill outcomes, presented in Figure 1, and included the effect size or mean test scores.

Information Sources and Search

Studies were identified by searching five electronic databases and scanning reference lists of articles. The five databases were: SCOPUS, Web of Science, PUBMED, Education Research Complete + ERIC + PsycINFO (EBSCO) and ProQuest Central. Search limits were set for English and peer reviewed articles only. The first search was run on $1^{\text {st }}$ June 2017 and the last search was completed on the 6th of December 2018. The following search strategy was used: 
(intervention OR program* OR random* OR trial OR pilot) AND ("fine motor" OR "visual motor" OR graphomotor) AND (child* OR preschool* OR "pre-school*" OR toddler* OR kinder* OR newborn OR infan*) NOT (disorder* OR illness OR disease* OR disab*). There was no restriction on publication date.

\section{Study Selection}

After running the search strategy, the first author removed all duplicates and the remaining article titles and abstracts were screened by two authors (KFBS and SLCV) in a blinded standardized manner. Titles and abstracts were categorized into three groups, 'yes', 'no' and 'maybe', and decision disagreement was resolved by discussion. The full text of the remaining articles was retrieved. One author (KFBS) screened all full text articles, and blinded to these results, the three other authors each screened one-third of the full text articles for inclusion. After completion, inclusion disagreement was discussed with all authors until full agreement was reached.

\section{Data Collection Process}

After study selection, the first author extracted data from included studies and other authors checked these data. Data were extracted on methodology, participant characteristics, intervention description, fine motor measurement and the results related to fine motor skill development.

Data items

The following information was extracted from each included study: (1) characteristics of participants, including sex, mean age and age range; (2) type of intervention, including name, type, facilitator, intensity, duration, groups and measurement tool(s) used; (3) results, including follow up, control group, statistical tests, effects of intervention, pre- and posttest scores.

\section{Risk of Bias in Individual Studies}

The first author assessed risk of bias for all included studies, and blinded to these results, the three other authors each assessed one-third of the studies using a checklist adapted from the Consolidated Standard of Reporting Trials statement (see Table 1) ${ }^{30}$ In line with recommendations from the PRISMA statement, the nine-item criteria were scored separately rather than assigning an overall score. Each item on the checklist was given either: "explicitly described and present" (Y), "absent" (N), "unclear or inadequately described" (?) or not applicable because of the study design (N/A). Disagreement between authors was discussed until consensus was reached.

Synthesis of Results

Meta-analyses were conducted using Review Manager version 5.3. ${ }^{31}$ Studies that included a control or comparison group and provided the number of participants, and pre- and post-test values (means and SD, change) for fine motor, visual motor or manual dexterity were included in the meta-analyses. Post-test values were used for the meta-analyses. Outcome data for fine motor and visual motor and manual dexterity were represented separately to enhance interpretability of meta-analyses results. Due to the variety of assessment tools, the standardized mean difference (SMD) with $95 \%$ confidence interval was reported. Statistical heterogeneity was assessed via $\mathrm{I}^{2}$ index test. Effect sizes were interpreted as small (0.3), moderate $(0.5)$ or large $(0.8) .{ }^{32}$ In one study, there were multiple treatment groups and one control group, therefore the sample size of the control group was divided to avoid double counting. ${ }^{33}$ 


\section{Study Selection Process}

\section{RESULTS}

The review flowchart is presented in Figure 2. The search strategy in multiple databases identified a total of 1691 studies and a further six were added through other sources (e.g. screening of reference lists). After removing duplicates $(n=715)$ and screening title and abstract ( $n=910), 66$ full-text articles were retrieved and assessed. Interrater reliability for the full text screening between the authors indicated an overall good agreement for the 66 articles (percentage agreement $86 \%, \kappa=0.73$ ). A total of 31 studies were included in the review and 19 of these were included in the meta-analyses.

Study Characteristics

Table 2 displays the characteristics of the studies. Three studies were published before $2000,{ }^{34-36}$ eight between 2000 and $2009^{8,27,33,37-41}$ and the majority (n=20) after 2009..$^{28,42-60}$ Studies were conducted in 12 countries, with the majority in the United States $(n=10)$ $8,35,37,40,44,48,49,52,53,57$ and Israel $(n=7) .27,33,36,39,41,43,47$ Most interventions $(n=24)$ were evaluated in a school setting and four interventions were in a home/community setting. ${ }^{51,55,58,59}$ For the remaining three studies, the intervention setting was unclear. ${ }^{35,54,56}$

A total of 3487 children participated across all studies with sample sizes ranging from 25 to 534 children. While taking into consideration the unclear description of retention in several studies, ${ }^{8,27,36,51,53,55-57}$ data of 3224 children were used for analyses. Approximately $56 \%$ of the participants were in the intervention groups. Two studies included only boys. ${ }^{43,47}$ There were 14 RCTs, ${ }^{27,33,35,36,39,41,43,49,50,53-55,57,58} 13$ quasi-experimental, ${ }^{8,28,34,44-48,51,52,56,59,60}$ three single group, ${ }^{37,38,40}$ and one repeated-measures study design. ${ }^{42}$

\section{Risk of Bias Within Studies}

The risk of bias analyses is presented in Table 3. Interrater reliability for the risk of bias assessment between the authors indicated an overall good agreement for all 279 items (percentage agreement $89 \%, \kappa=0.80$ ). Baseline characteristics were presented and statistically tested in 23 of the 31 studies. $^{27,28,34,37-39,41-46,48-55,58-60}$ Seventeen studies described their randomization process $8,27,33,35,36,39,41-43,49-51,53,55,57,58,60$ and assessor blinding was reported in nine studies. ${ }^{33,35,43,47-49,53,59,60}$ The validation of the assessments used was reported or cited in 29 of the 31 studies. ${ }^{8,27,28,33,34,36-41,43-60}$ The dropout rate was clearly described in 10 studies ${ }^{8,37,39,41,44-46,58-60}$ and five studies reported conducting a power calculation. ${ }^{43,44,47,56,59}$ In one study, the intention-to-treat approach for analyses was adequately reported and in 16 studies the analyses accounted for covariates. ${ }^{8,27,28,33,35,39,41,42,45,47,50-52,56,57,59}$ A summary of the results per group or estimated effect size with precision was reported in 24 studies. $8,27,28,33,34,37-41,43-45,47-52,55,57,59,60$

\section{Measurement of Fine Motor Skills}

Fourteen different assessment tools were used across all 31 studies to measure fine motor skill development. Information on the use of each assessment is presented in Table 4, which was formatted by using data from the 31 included papers. The most common assessments were editions of: The Beery-Buktenica Developmental test of Visual-Motor Integration (The Beery VMI; $n=14), 8,27,33,36,39-41,43,44,46-49,53,60$ the Developmental Test of Visual Perception (DTVP; $n=6),{ }^{27,33,37,39,41,54}$ the Bruininks-Oseretsky Test of Motor Proficiency (BOT; $n=5),{ }^{39,44,49,50,59}$ and the Peabody Developmental Motor Scales (PDMS; $\left.n=4\right) .{ }^{37,40,45,57}$

Types of Interventions 
Most studies included one intervention group and one control group. One study evaluated two intervention groups with one control group ${ }^{33}$ and one study included three intervention groups and one control group. ${ }^{27}$ There were three studies without a control group, ${ }^{37,38,40}$ four studies with two intervention groups and no control group, ${ }^{41,47,48,59}$ and one study with one intervention group and two control groups. ${ }^{56}$ Nine interventions were facilitated by teachers, ${ }^{36,42,43,47,50,52,53,57,60}$ six interventions by Occupational Therapists or Occupational Therapist students, ${ }^{8,33,37-39,48}$ two interventions by researchers, ${ }^{28,54}$ two interventions by parents, ${ }^{58,59}$ one intervention by trained professionals/ personnel, ${ }^{45}$ seven interventions by a combination of these experts, ${ }^{27,40,41,44,49,51,55}$ and four intervention studies inadequately described their facilitators. ${ }^{34,35,46,56}$ The intervention length varied from eight weeks to 16 months with an average duration of approximately 23 weeks ( 5.3 months). Three studies completed child assessments on three time-points, ${ }^{47,50,55}$ for two of these studies it was classified as follow-up assessments. ${ }^{50,55}$ Five studies provided unclear descriptions of the estimated time and/or duration of the intervention. $27,38,41,54,56$ Three studies were inconsistent when reporting their intervention time spent per participant, which resulted in a total calculated estimation time of more than 83 hours. ${ }^{51,52,58}$ The average intervention time of the remaining 23 studies was 20 hours (range $9-35$ hours).

Eleven studies implemented an intervention program that mainly focused on fine motor skill activities, ${ }^{33,36,39,46,48,52-54,56,59,60}$ nine studies implemented fine and gross motor skill activities, ${ }^{8,28,34,35,44,45,50,55,57}$ one study used only gross motor activities but still reported fine motor skill outcomes, ${ }^{42}$ and one study provided only consultant visits. ${ }^{38}$ There were nine interventions programs combining motor activities with consultancy protocols. ${ }^{27,37,40,41,43,47,49,51,58}$

Evidence for Outcomes

Twenty studies reported statistically significant intervention effects on fine motor skill outcomes (e.g. fine or visual motor). ${ }^{27,33-35,37,39,40,42-46,49-52,54-57}$ Of these, nine studies reported significant intervention effects on fine motor, ${ }^{35,42,44,50-52,55,56,59}$ seven studies on visual motor, $27,33,34,43,46,54,57$ and four studies on both fine and visual motor. ${ }^{37,40,45,49}$ Furthermore, Tzuriel and Eiboshitz ${ }^{36}$ found a positive effect on visual motor integration and Hartigner et al. ${ }^{58}$ on fine motor, although they provided no test of statistical significance. Lin et al. ${ }^{59}$ and Axford et al. ${ }^{60}$ were the only two studies that used a touch-screen tablet intervention and compared this with a typical fine motor activity group. Lin et al. ${ }^{59}$ found significant differences as a result of a decrease of fine motor integration and manual dexterity in the touch-screen group, and an increase in the fine motor activity group. Conversely, Axford et al. ${ }^{60}$ presented significant differences in motor coordination in favor of the touch-screen (i.e., iPad) group compared to control. Additionally, they found a significant increase on visual motor integration for both iPad and control group. Six studies reported no statistically significant intervention effects on fine motor skill outcomes. ${ }^{8,38,41,47,48,53}$ Five out of these six studies used the Beery VMI assessment. ${ }^{8,41,47,48,53}$ Nonetheless, The Beery VMI was also used in six studies that did show significant intervention effects in six studies. ${ }^{33,40,43,46,49,60}$ Ratzon and colleagues ${ }^{41}$ found significant improvement in both the intervention and control group but no differences between groups. Erasmus et al. ${ }^{28}$ found an increase of fine motor skills in both the intervention and control group, however, the increase in the control group was significantly greater. Still, their intervention showed a moderate effect on the overall test results and visual perception.

Thirteen short-term (range 9 weeks - 5 months) 27,33,35,36,39,42,46,49,50,55-57,60 and ten long-term (range $6-13.2$ months) $34,37,40,43,44,51-54,58$ interventions were effective at increasing fine or 
visual motor development. Five short-term (range 8 weeks to 5 months) $28,38,41,48,53$ and three long-term ( 8 and 16 months) ${ }^{8,47,59}$ yielded intervention effects that were not significant or had opposite effects. Only one study reported significant sex differences, with boys scoring significantly better than girls on the fine motor skills outcome..$^{50}$

\section{Meta-analyses of Intervention Effects}

A variety of assessment tools were included for the fine motor outcome data; i.e. BOT-2, DDST II, Le Roux's Group Test and BAS II. Assessment tools included for visual motor comparison were The Beery VMI (all editions), PDMS-2 and Visual-motor sequential subtest of the ITPA. For manual dexterity three assessment tools were included; i.e. M-ABC, MABC-2, and BOT-2. Lin et al. ${ }^{59}$ had two interventions groups, the typical fine motor activity group was classified as intervention and the touch-screen tablet group as control to be comparable with other studies. However for Axford et al. ${ }^{60}$ this was the opposite, due to their clear description of which group was the experimental group (i.e. iPad) and control group (i.e. fine motor activities). Random effects models were used for all analyses due to the substantial heterogeneity for fine motor and visual motor outcomes and the minimal heterogeneity for manual dexterity outcomes among the interventions. The meta-analyses showed moderated effect sizes for fine motor outcomes ( $\mathrm{SMD}=0.68,95 \% \mathrm{CI} 0.39-0.96, Z$ $=4.61, p<0.00001$; Figure 3$)$, visual motor outcomes $(\mathrm{SMD}=0.57,95 \% \mathrm{CI} 0.37-0.76, Z=$ $5.73, p<0.00001$; Figure 4) and manual dexterity $(\mathrm{SMD}=0.52,95 \% \mathrm{CI} 0.24-0.80, Z=$ $3.65, p=0.0003$; Figure 5). For visual motor outcomes a funnel plot was made to assess bias, presented in Figure 6 . The funnel plot revealed three studies outside the $95 \%$ CI lines, which suggest possible bias. ${ }^{8,36,54}$ The funnel plot for the fine motor outcomes and manual dexterity were not produced as the meta-analyses included less than 10 interventions. $^{61}$

\section{DISCUSSION}

The purpose of this systematic review and associated meta-analyses was to describe and evaluate the efficacy of motor skill intervention programs on fine motor skill outcomes in typically developing children aged birth to six years. Overall, twenty-five of the 31 studies reported positive intervention effects on fine motor skill outcomes. Furthermore, the metaanalyses revealed moderate effect sizes of motor skill programs on fine motor, visual motor and manual dexterity outcomes. The findings are promising, however need to be interpreted with caution due to the high risk of bias in many of the studies.

Fine motor skill promotion is an upcoming research field, supported by the majority of intervention studies $(n=20)$ that have been published in the last 10 years. Overall, there were substantial differences between intervention settings, facilitators, length and content. Only four $(13 \%)$ studies were delivered at home, whereas 24 (78\%) were delivered in a schoolbased setting. Twenty-seven studies adequately described the facilitators of the interventions, and six different facilitators were identified (i.e. led by teacher, Occupational Therapist or Occupational Therapist students, parent, researcher, trained personnel or a combination of these). Seven of the nine teacher-led, three of the six Occupational Therapist-led, and six of the seven combined-led intervention programs were efficacious. The other five studies were led by parents, researcher or trained personnel. Positive intervention effects were found in one of the two parent-led, one of the two researcher-led, and in the only trained personnel-led programs. Hence, future studies should carefully consider the setting and facilitators of the intervention as this can play an important role in positively impacting child outcomes. Furthermore, neither the sample size nor the length of the intervention appeared to play a part in enhancing the likelihood of revealing positive results. All studies with a sample size larger than 80 participants $(n=11)$ and an additional 14 studies $(70 \%)$ with a sample size smaller 
than 80 were found to have a significant effect. Both short-term ( $<6$ months) and long-term ( $>6$ months) interventions showed positive effects. Although many of these interventions are successful, questions are raised about the long-term effects of such interventions. Only two studies collected follow-up data to evaluate the effects after the intervention period. The first study showed an increase in fine motor skills from post-test to follow-up (6 months), however the control group also showed an increase in fine motor skills and therefore, no significant difference between groups was found. ${ }^{50}$ The second study showed that the intervention effects fade out three weeks post-intervention. ${ }^{55}$ It is also possible that the lack of sustainability is caused by the ongoing costs of implementing an intervention after support from professionals ceases. Based on these limited findings, it will be important to examine additional methods to enhance children's fine motor development in a sufficient and sustainable manner.

Although clear differences for program content exist, discrepancy between fine and/or gross motor activities and/or consultancy was made to categorize content diversity. Intervention programs that incorporated fine and/or gross motor activities revealed to have a high change of increasing children's fine motor skills. Consultancy visits alone do not appear to increase children's fine motor skills effectively. ${ }^{38}$ This suggests that to increase children's fine motor skills, intervention programs need to at least implement fine and/or gross motor skill activities to be valuable.

Many of the studies reviewed used occupational therapy models as the content of the intervention. These models included indirect services (e.g. consultancy with parents/ educators) and direct services (e.g. group and/ or individual fine or gross motor activities). ${ }^{27,37,40,41,43,47,49,51,58}$ Few studies reported the theoretical framework for or pedagogical approach of their interventions. ${ }^{33,36,39}$ For example, Tzuriel and Eiboshitz's ${ }^{36}$ intervention (Structured Program of Visual-Motor Integration) was based on three theoretical domains: (1) those that emphasize visual-motor development, (2) those that stress the need for visual-motor mastery as a basic preschool skill and (3) mediated learning experience theory (i.e. structured stimulating experiences within the child's environment). ${ }^{36}$ Another theoretically motivated intervention was conducted by Ratzon et al. ${ }^{39}$ based on motor learning theories (i.e. the practiced tasks should be as similar as possible to the required assignment) and multisensory theory. ${ }^{39}$ Although these two interventions were based on different theoretical frameworks, both were effective in increasing visual motor outcomes. $^{36,39}$ This is likely due to the increase of fine motor-related practices and experiences in both programs. Lahav et al. ${ }^{33}$ compared two interventions using different pedagogical approaches with a control group. One intervention (Directive Visual Motor Intervention (DVMI)) was based on the theory of Ratzon et al. ${ }^{39}$ while the other (Nondirective Supportive Intervention (NDSI)) did not incorporate any specific fine motor activities. Interestingly, the NDSI was the most effective in increasing visual motor integration outcomes. ${ }^{33}$ Future research is needed to clarify the optimal theoretical and pedagogical approaches to increase fine motor skills. This will assist researchers and practitioners when selecting programs to support children's outcomes.

It is difficult to pinpoint strong associations between the intervention characteristics and the effectiveness of the intervention because of the differences in interventions designs and methodology. The current meta-analyses found promising medium effect sizes for the majority of the included studies. The overall effect size for visual motor was slightly higher than fine motor and manual dexterity. These results should be interpreted with caution however, due to the low heterogeneity and high risk of bias between studies found within the 
meta-analyses. Interestingly, two studies within the meta-analyses were found to have negative effect sizes, which indicates that those interventions had a lower increase of children's fine/visual motor performances compared with the control groups. ${ }^{8,28}$ Not only the suggested bias found in the funnel plot of the meta-analyses needs to be considered carefully, this review also found high risk of bias in most studies. Even though baseline characteristics were well-described, a valid measurement tool was used and a summary of results was presented, less than one-third of the studies sufficiently defined assessor blinding, drop out methodology, power calculations and the intention-to-treat analyses.

\section{Strengths and Limitations}

This study is the first review that evaluates the effects of motor skill interventions on fine motor skill development of typically developing children in the early years. This review has various strengths: (1) alignment with the PRISMA Statement (2) extensive search of multiple databases with large inclusion criteria and no date restriction, (3) robust systematic search methodology and comprehensive study inclusion details, (4) large percentage of agreement between authors within full text screening and risk of bias analyses. Yet, the results of the review need to be interpreted carefully due to the following limitations: (1) the search was restricted to English journal articles only, (2) the high risk of bias in numerous included studies (Table 3), (3) meta-analyses for manual dexterity included only three studies of which two studies were from the same author, (4) substantial differences in study methodology (e.g. intervention content, measurement tool use) which made it difficult to compare study results.

\section{Implications for Future Research}

Fine motor skills are key for children's early development. More research is needed to establish strong evidence based pedagogical approaches and intervention components, which are associated with increasing children's fine motor skill abilities. In addition, due to the large range of terminology that is linked with fine motor skills, a theoretical review of the literature might assist to a better understanding of fine motor acquisition. Not only is evidence-based research needed to help better understand fine motor development as a whole, but future intervention studies should also consider various strategies such as; setting and facilitators, sample size, content, assessment and measurement period. More specifically, studies should value the collaboration between researchers and intervention facilitators; as most studies in this review were conducted within educational settings, teacher and researcher interactions are important to support each other to optimize the effects on children's development. It is also important to conduct and report on the sample size calculations to ensure appropriate statistical analyses are completed. Furthermore, studies should clearly describe intervention content and components to ensure intervention programs can be easily compared, which can help to comprehend the methodology to effectively promote fine motor development in the early years. As presented in this review, there is a large variety of assessment tools available and only few studies reported on follow-up data. Therefore, future studies should thoroughly reflect on the assessment tool and measurement period they select. In that way, future reviews and meta-analyses will be able to compare intervention effects more accurate and examine long term intervention effects.

\section{CONCLUSION}

It is highlighted by this review that fine motor development in the early years is an extensive upcoming field of interest by many researchers worldwide. This review paper presents evidence on the positive effects of intervention programs that aim to enhance fine motor skills for young children. However, results must be treated with caution due to the high risk of bias found in many studies. This review also identifies that there is a large variability 
between study settings, designs and methodologies. Nonetheless, many of the interventions were shown to increase children fine motor skill performances. Given the robust associations between fine motor skills and other domains of learning and development, ${ }^{11,12,14}$ future research is needed to examine high-quality intervention programs with long-term follow-up.

\section{References}

1. Department of Education Employment and Workplace Relations (DEEWR). Belonging, Being \& Becoming: The Early Years Learning Framework for Australia. In. Canberra, ACT: Commonwealth of Australia; 2009.

2. Office of Head Start. Head Start Early Learning Outcomes Framework: Ages Birth to Five. In. Washington, DC; 2015.

3. Bello AI, Quartey JN, Appiah LA. Screening for developmental delay among children attending a rural community welfare clinic in Ghana. BMC Pediatr. 2013;13:119.

4. Handel AJ, Lozoff B, Breiilh J, et al. Sociodemographic and nutritional correlates of neurobehavioral development- A study of young children in a rural region of Ecuador. Rev Panam Salud Publica. 2007;21(5):292-300.

5. Troude P, Squires J, L'Helias LF, et al. Ages and Stages Questionnaires: feasibility of postal surveys for child follow-up. Early Hum Dev. 2011;87(10):671-676.

6. Goyen T, Lui K. Longitudinal motor development of apparently normal high-risk infants at 18 months, 3 and 5 years. Early Hum Dev. 2002;70:103-115.

7. Luo Z, Jose PE, Huntsinger CS, et al. Fine motor skills and mathematics achievement in East Asian American and European American kindergartners and first graders. Brit J Dev Psychol. 2007;25(4):595-614.

8. Dankert HL, Davies PL, Gavin WJ. Occupational therapy effects on visual-motor skills in preschool children. Am J Occup Ther. 2003;57:542-549.

9. Wang YC, Magasi SR, Bohannon RW, et al. Assessing dexterity function: a comparison of two alternatives for the NIH Toolbox. J Hand Ther. 2011;24(4):313321.

10. Wassenberg R, Kessels AGH, Kalff AC, et al. Relation between cognitive and motor performance in 5- to 6-year-old children- results from a large-scale cross-sectional study. Child Dev. 2005;76(5):1092-1103.

11. Oberer N, Gashaj V, Roebers CM. Motor skills in kindergarten: Internal structure, cognitive correlates and relationships to background variables. Hum Mov Sci. 2017;52:170-180.

12. Cameron CE, Brock LL, Murrah WM, et al. Fine motor skills and executive function both contribute to kindergarten achievement. Child Dev. 2012;83(4):1229-1244.

13. Roebers CM, Rothlisberger M, Neuenschwander R, et al. The relation between cognitive and motor performance and their relevance for children's transition to school: a latent variable approach. Hum Mov Sci. 2014;33:284-297.

14. Son S-H, Meisels SJ. The Relationship of Young Children's Motor Skills to Later School Achievement. Merrill Palmer Quart. 2006;52(4):755-778.

15. Grissmer D, Grimm KJ, Aiyer SM, et al. Fine Motor Skills and Early Comprehension of the World: Two New School Readiness Indicators. Dev Psychol. 2010;46(5):10081017.

16. Pitchford NJ, Papini C, Outhwaite LA, et al. Fine Motor Skills Predict Maths Ability Better than They Predict Reading Ability in the Early Primary School Years. Front Psychol. 2016;7.

17. Dinehart L, Manfra L. Associations Between Low-Income Children's Fine Motor Skills in Preschool and Academic Performance in Second Grade. Early Educ Dev. 2013;24(2):138-161. 
18. Bart O, Hajami D, Bar-Haim Y. Predicting school adjustment from motor abilities in kindergarten. Infant Child Dev. 2007;16(6):597-615.

19. Livesey D, Keen J, Rouse J, et al. The relationship between measures of executive function, motor performance and externalising behaviour in 5- and 6-year-old children. Hum Mov Sci. 2006;25(1):50-64.

20. OECD. Enrolment rate by age. 2016; Available at: https://stats.oecd.org/viewhtml.aspx?datasetcode=EAG_ENRL_RATE_AGE\&lang=e n. Accessed December 6, 2018.

21. Marr D, Cermak S, Cohn ES, et al. Fine motor activities in Head Start and kindergarten classrooms. Am J Occup Ther. 2003;57:550-557.

22. Van Capelle A, Broderick CR, van Doorn N, et al. Interventions to improve fundamental motor skills in pre-school aged children: A systematic review and metaanalysis. J Sci Med Sport. 2017;20(7):658-666.

23. Veldman SL, Jones RA, Okely AD. Efficacy of gross motor skill interventions in young children: an updated systematic review. BMJ Open Sport Exerc Med. 2016;2(1):e000067.

24. Wick K, Leeger-Aschmann CS, Monn ND, et al. Interventions to Promote Fundamental Movement Skills in Childcare and Kindergarten: A Systematic Review and Meta-Analysis. Sports Med. 2017;47(10):2045-2068.

25. Case-Smith J, Frolek Clark GJ, Schlabach TL. Systematic review of interventions used in occupational therapy to promote motor performance for children ages birth-5 years. Am J Occup Ther. 2013;67(4):413-424.

26. Moher D, Liberati A, Tetzlaff J, et al. Preferred reporting items for systematic reviews and meta-analyses: the PRISMA statement. PLoS Med. 2009;6(7):e1000097.

27. Ratzon NZ, Lahav O, Cohen-Hamsi S, et al. Comparing different short-term service delivery methods of visual-motor treatment for first grade students in mainstream schools. Res Dev Disabil. 2009;30(6):1168-1176.

28. Erasmus M, van Rensburg OJ, Pienaar AE, et al. The effect of a perceptual-motor intervention programme on learning readiness of Grade $\mathrm{R}$ learners from South African deprived environments. Early Child Dev Care. 2015;186(4):596-611.

29. Suggate S, Pufke E, Stoeger $\mathrm{H}$. The effect of fine and grapho-motor skill demands on preschoolers' decoding skill. J Exp Child Psychol. 2015;141:24-48.

30. Schulz KF, Altman DG, Moher D. CONSORT 2010 statement- updated guidelines for reporting parallel group randomized trials. PLos Med. 2010;7(3):726-732.

31. Review Manager (RevMan) [computer program]. Version 5.3. Copenhagen: The Nordic Cochrane Centre, The Cochrane Collaration; 2014.

32. Cohen J. Statistical power analysis for the behavioral sciences. Hillsdale: Lawrence Erlbaum Associates; 1988.

33. Lahav O, Apter A, Ratzon N. A comparison of the effects of directive visuomotor intervention versus nondirective supportive intervention in kindergarten and elementary school children. J Neural Transm 2008;115(8):1231-1239.

34. McCormick CC, Schnobrich JN. Perceptual-motor training and improvement in concentration in a Montessori preschool. Percept Mot Skills. 1971;32:71-77

35. Gabbard CP. Visual-motor training and performance on a fine motor task by kindergarten children. Percept Motor Skills. 1978;47(3):950-950.

36. Tzuriel D, Eiboshitz Y. Structured program of visual-motor integration (SP-VMI) for preschool children. Learn Individ Differ. 1992;4(2):103-124.

37. Case-Smith J. Effects of occupational therapy services on fine motor and functional performance in preschool children. Am J Occup Ther. 2000;54:372-380. 
38. Bayona C, McDougall J, Tucker MA, et al. School-Based Occupational Therapy for Children with Fine Motor Difficulties. Phys Occup Ther Pediatr. 2006;26(3):89-110.

39. Ratzon NZ, Efraim D, Bart O. A short-term graphomotor program for improving writing readiness skills of first-grade students. Am J Occup Ther. 2007;61:399-405.

40. Bazyk S, Michaud P, Goodman G, et al. Integrating Occupational Therapy Services in a Kindergarten Curriculum A Look at the Outcomes. Am J Occup Ther. 2009;63:160171.

41. Ratzon NZ, Zabaneh-Tannas K, Ben-Hamo L, et al. Efficiency of the home parental programme in visual-motor home activity among first-grade children. Child Care Health Dev. 2009;36(2):249-254.

42. Brown CG. Improving fine motor skills in young children: An intervention study. Educ Psychol Prac. 2010;26(3):269-278.

43. Golos A, Sarid M, Weill M, et al. Efficacy of an Early Intervention Program for AtRisk Preschool Boys: A Two-Group Control Study. Am J Occup Ther. 2011;65(4):400-408.

44. Lust CA, Donica DK. Effectiveness of a handwriting readiness program in head startA two-group controlled trial. Am J Occup Ther. 2011;65:560-568.

45. Pienaar AE, Van Rensburg E, Smit A. Effect of a kinderkinetics programme on components of children's perceptual-motor and cognitive functioning. Phys Educ Recr. 2011;33(3):113-128.

46. Dibek E. Implementation of visual motor ability enhancement program for 5 years old. Procd Soc Behv. 2012;46:1924-1932.

47. Golos A, Sarid M, Weill M, et al. The Influence of Early Intervention Length on the Participation of Low Socioeconomic At-Risk Preschool Boys: A Two-Group Control Study. Journal of Occupational Therapy, Schools, \& Early Intervention. 2013;6(3):188-202.

48. Howe TH, Roston KL, Sheu CF, et al. Assessing handwriting intervention effectiveness in elementary school students: a two-group controlled study. Am J Occup Ther. 2013;67(1):19-26.

49. Ohl AM, Graze H, Weber K, et al. Effectiveness of a 10-week tier-1 response to intervention program in improving fine motor and visual-motor skills in general education kindergarten students. Am J Occup Ther. 2013;67(5):507-514.

50. Piek JP, McLaren S, Kane R, et al. Does the Animal Fun program improve motor performance in children aged 4-6 years? Hum Mov Sci. 2013;32(5):1086-1096.

51. Janssens W, Rosemberg C. The impact of a Caribbean home-visiting child development program on cognitive skills. Econ Educ Rev. 2014;39:22-37.

52. Bhatia P, Davis A, Shamas-Brandt E. Educational gymnastics: The effectiveness of montessori practical life activities in developing fine motor skills in kindergartners. Early Educ Dev. 2015;26(4):594-607.

53. Pfeiffer B, Moskowitz B, Paoletti A, et al. Developmental Test of Visual-Motor Integration (VMI): An Effective Outcome Measure for Handwriting Interventions for Kindergarten, First-Grade, and Second-Grade Students? Am J Occup Ther. 2015;69(4).

54. Jeon HR, Im JN, Choi HJ, et al. The influence of imagery training on the visual perception development of children with disadvantaged background. Turk Online $J$ Educ T. 2016;2016:931-939.

55. Ulutas A, Aksoy AB. The effect of the home-centered mother-infant interaction program on infant development through mutual interaction and mothers' intuitive behaviors. Education and Science. 2016;41(186):53-67. 
56. Zoghi A, Shojaei M, Ghasemi A. The Impact of a Motor Affordance Intervention on Motor and Cognitive Development of Young Children. Int J Ment Health Ad. 2016;14(5):743-750.

57. Hamilton M, Liu T. The Effects of an Intervention on the Gross and Fine Motor Skills of Hispanic Pre-K Children from Low SES Backgrounds. Early Childhood Educ J. 2017;46(2):223-230.

58. Hartinger SM, Lanata CF, Hattendorf J, et al. Impact of a child stimulation intervention on early child development in rural Peru: A cluster randomised trial using a reciprocal control design. J Epidemiol Commun H. 2017;71(3):217-224.

59. Lin LY, Cherng RJ, Chen YJ. Effect of Touch Screen Tablet Use on Fine Motor Development of Young Children. Phys Occup Ther Pediatr. 2017;37(5):457-467.

60. Axford C, Joosten AV, Harris C. iPad applications that required a range of motor skills promoted motor coordination in children commencing primary school. Aust Occup Ther J. 2018;65(2):146-155.

61. Sterne JA, Sutton AJ, Ioannidis JP, et al. Recommendations for examining and interpreting funnel plot asymmetry in meta-analyses of randomised controlled trials. BMJ. 2011;343:d4002. 


\section{FIGURE AND TABLE LEGENDS}

FIGURE 1 TERMINOLOGY linked to fine motor skills.

FIGURE 2 PRISMA flowchart of studies through the review process.

FIGURE 3 Meta-analyses comparing the intervention effects on Fine Motor outcome (Fine motor, Fine Motor Precision \& Fine Motor Integration).

FIGURE 4 Meta-analyses comparing the intervention effects on Visual Motor outcome (Visual Motor, Visual Motor Skills \& Visual Motor Integration).

FIGURE 5 Meta-analyses comparing the intervention effects on Manual Dexterity.

TABLE 1 Risk of Bias Checklist

TABLE 4 Measurements of Fine Motor Development

Supplemental Digital Content 1 - TABLE 2 Study/ Intervention Characteristics and Findings Supplemental Digital Content 2 - TABLE 3 Risk of Bias Assessment in Intervention Studies Examining changes in FM development

Supplemental Digital Content 3 - FIGURE 6 Funnel plot indication publication bias for Visual Motor outcome (Visual Motor, Visual Motor Skills \& Visual Motor Integration). 


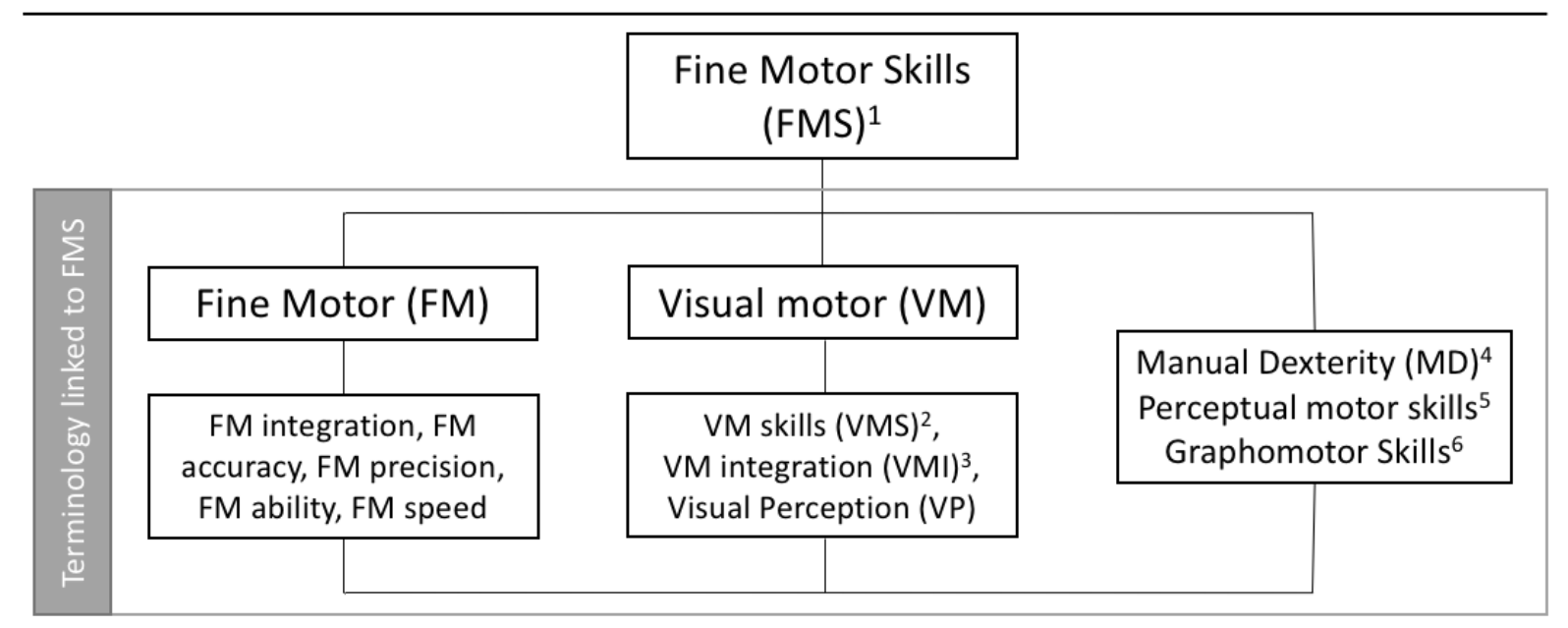

FIGURE 1 TERMINOLOGY linked to fine motor skills.

${ }^{1}$ Fine motor skills (i.e. involve smaller muscles movement to hold and manipulate small objects with the use of hands and fingers, which require eye-hand coordination), ${ }^{2}$ visual motor skills (i.e. integration of visual image with the correct motor response), ${ }^{3}$ visual motor integration (i.e. combination of visual perceptual abilities and fine motor control), ${ }^{4}$ manual dexterity (i.e. coordination and manipulation of objects in a timely manner), ${ }^{5}$ perceptual motor skills (i.e. combination of sensory and motor skills) and ${ }^{6}$ graphomotor skills (i.e. coordination of perceptual, cognitive and motor skills to write) 


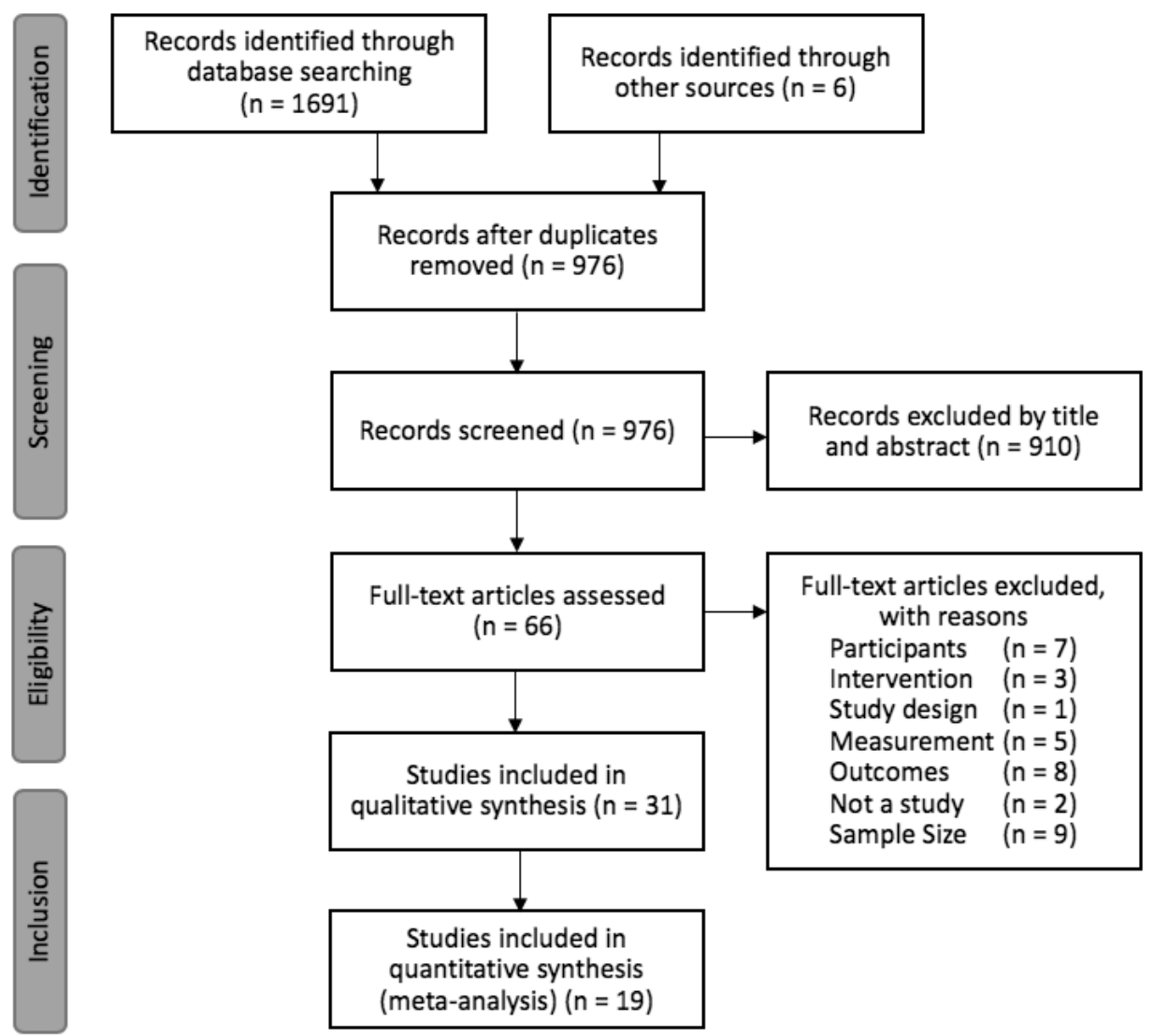

FIGURE 2 PRISMA flowchart of studies through the review process. 


\begin{tabular}{|c|c|c|c|c|c|c|c|c|c|c|}
\hline \multirow[b]{2}{*}{ Study or Subgroup } & \multicolumn{3}{|c|}{ Intervention } & \multicolumn{3}{|c|}{ Control } & \multicolumn{2}{|c|}{ Std. Mean Difference } & \multirow{2}{*}{\multicolumn{2}{|c|}{$\begin{array}{l}\text { Std. Mean Difference } \\
\text { IV, Random, } 95 \% \mathrm{Cl}\end{array}$}} \\
\hline & Mean & SD & Total & Mean & SD & Total & Weight & IV, Random, 95\% CI & & \\
\hline \multicolumn{11}{|c|}{ 4.1.1 Fine Motor Precision } \\
\hline Lin 2017 & 22.1 & 4.4 & 40 & 18.6 & 4 & 40 & $12.1 \%$ & $0.82[0.37,1.28]$ & & \\
\hline $\begin{array}{l}\text { Lust } 2011 \\
\text { Subtotal }(95 \% \mathrm{Cl})\end{array}$ & 11.29 & 3.33 & $\begin{array}{l}17 \\
57\end{array}$ & 8.47 & 4.31 & $\begin{array}{l}15 \\
55\end{array}$ & $\begin{array}{r}8.3 \% \\
20.4 \%\end{array}$ & $\begin{array}{l}0.72[0.00,1.44] \\
0.79[0.41,1.18]\end{array}$ & & \\
\hline \multicolumn{11}{|c|}{$\begin{array}{l}\text { Heterogeneity: } \mathrm{Tau}^{2}=0.00 ; \mathrm{Chi}^{2}=0.06, \mathrm{df}=1(\mathrm{P}=0.81) ; \mathrm{I}^{2}=0 \% \\
\text { Test for overall effect: } \mathrm{Z}=4.03(\mathrm{P}<0.0001)\end{array}$} \\
\hline \multicolumn{11}{|c|}{ 4.1.2 Fine Motor Integration } \\
\hline Lin 2017 & 21 & 4.6 & 40 & 18.3 & 3.5 & 40 & $12.2 \%$ & $0.65[0.20,1.10]$ & & \\
\hline $\begin{array}{l}\text { Lust } 2011 \\
\text { Subtotal }(95 \% \mathrm{Cl})\end{array}$ & 12 & 5.37 & $\begin{array}{l}17 \\
57\end{array}$ & 7.47 & 5.08 & $\begin{array}{l}15 \\
55\end{array}$ & $\begin{array}{r}8.2 \% \\
20.4 \%\end{array}$ & $\begin{array}{l}0.84[0.11,1.57] \\
0.71[0.32,1.09]\end{array}$ & & \\
\hline \multicolumn{11}{|c|}{$\begin{array}{l}\text { Heterogeneity: } \text { Tau }^{2}=0.00 ; \mathrm{Chi}^{2}=0.19, \mathrm{df}=1(\mathrm{P}=0.67) ; \mathrm{I}^{2}=0 \% \\
\text { Test for overall effect: } \mathrm{Z}=3.61(\mathrm{P}=0.0003)\end{array}$} \\
\hline \multicolumn{11}{|l|}{ 4.1.3 Fine Motor } \\
\hline Brown 2010 & 54.66 & 11.66 & 32 & 45.4 & 7.63 & 33 & $11.2 \%$ & $0.93[0.42,1.45]$ & & \\
\hline Erasmus 2015 & 0.9 & 2.14 & 21 & 1.59 & 1.86 & 27 & $10.3 \%$ & $-0.34[-0.92,0.23]$ & & - \\
\hline Ohl 2013 & 48.39 & 10.32 & 47 & 45.57 & 8.86 & 28 & $11.9 \%$ & $0.28[-0.19,0.75]$ & - & \\
\hline Pienaar 2011 & 2.62 & 2.82 & 13 & -0.12 & 6.19 & 19 & $8.3 \%$ & $0.52[-0.20,1.24]$ & 7 & \\
\hline Ratzon 2007 & 27.2 & 3.3 & 15 & 21.38 & 5.07 & 24 & $8.4 \%$ & $1.27[0.56,1.98]$ & & \\
\hline $\begin{array}{l}\text { Ulutas } 2016 \\
\text { Subtotal }(95 \% \mathrm{Cl})\end{array}$ & 5.32 & 0.57 & $\begin{array}{r}22 \\
150\end{array}$ & 4.64 & 0.49 & $\begin{array}{r}22 \\
153\end{array}$ & $\begin{array}{r}9.2 \% \\
59.2 \%\end{array}$ & $\begin{array}{c}1.26[0.60,1.91] \\
0.64[0.14,1.13]\end{array}$ & & \\
\hline \multicolumn{11}{|c|}{$\begin{array}{l}\text { Heterogeneity: } \text { Tau }^{2}=0.29 ; \mathrm{Chi}^{2}=21.00, \mathrm{df}=5(\mathrm{P}=0.0008) ; \mathrm{I}^{2}=76 \% \\
\text { Test for overall effect: } \mathrm{Z}=2.51(\mathrm{P}=0.01)\end{array}$} \\
\hline Total $(95 \% \mathrm{Cl})$ & & & 264 & & & 263 & $100.0 \%$ & $0.68[0.39,0.96]$ & & \\
\hline \multicolumn{9}{|c|}{$\begin{array}{l}\text { Heterogeneity: } \mathrm{Tau}^{2}=0.12 ; \mathrm{Chi}^{2}=22.16, \mathrm{df}=9(\mathrm{P}=0.008) ; \mathrm{I}^{2}=59 \% \\
\text { Test for overall effect: } \mathrm{Z}=4.61(\mathrm{P}<0.00001) \\
\text { Test for subqroup differences: } \mathrm{Chi}^{2}=0.26, \mathrm{df}=2(\mathrm{P}=0.88), \mathrm{I}^{2}=0 \%\end{array}$} & $\begin{array}{cc}-1 \\
\text { Favours control }\end{array}$ & Fave \\
\hline
\end{tabular}

FIGURE 3 Meta-analyses comparing the intervention effects on Fine Motor outcome (Fine motor, Fine

Motor Precision \& Fine Motor Integration).

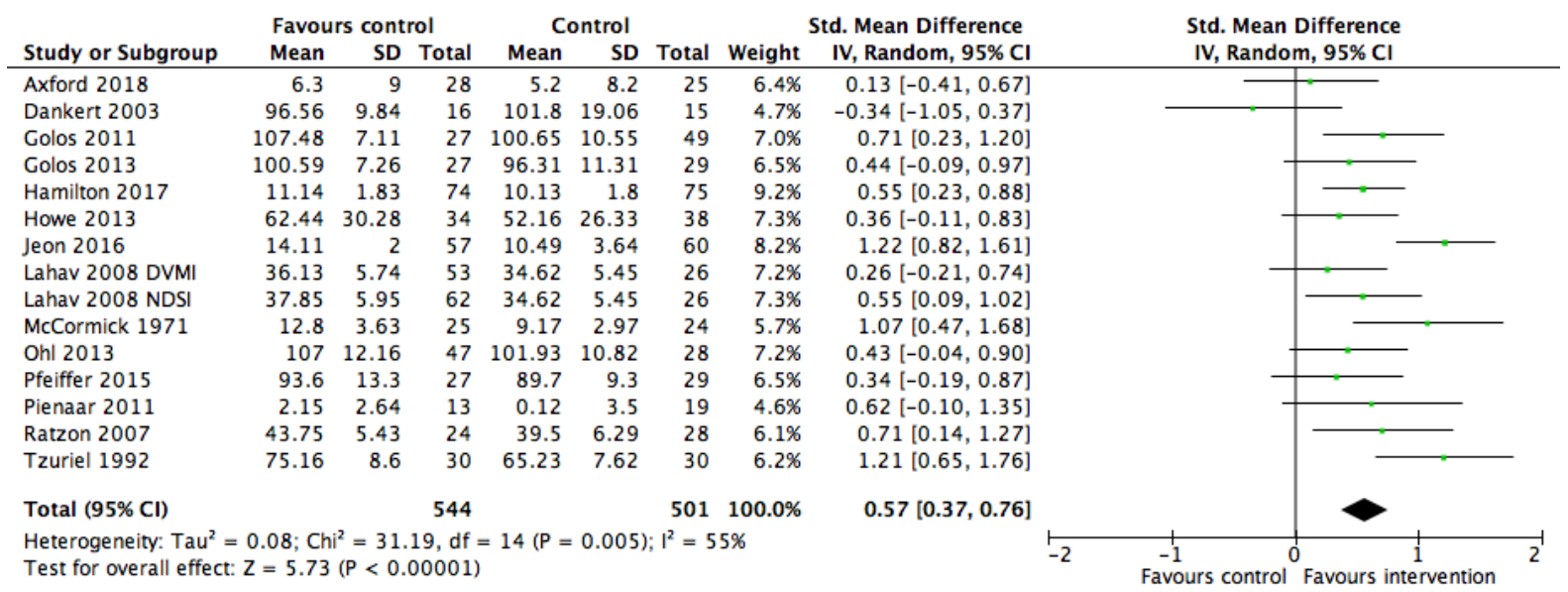

FIGURE 4 Meta-analyses comparing the intervention effects on Visual Motor outcome (Visual Motor,

Visual Motor Skills \& Visual Motor Integration).

\begin{tabular}{|c|c|c|c|c|c|c|c|c|c|c|c|}
\hline Study or Subgroup & \multicolumn{3}{|c|}{ Experimental } & \multicolumn{3}{|c|}{ Control } & \multicolumn{2}{|r|}{ Std. Mean Difference } & \multicolumn{3}{|c|}{$\begin{array}{l}\text { Std. Mean Difference } \\
\text { IV, Random, } 95 \% \mathrm{Cl}\end{array}$} \\
\hline Golos 2011 & -1.96 & 2.44 & 27 & -3.21 & 2.89 & 49 & $34.5 \%$ & $0.45[-0.02,0.93]$ & & & \\
\hline Golos 2013 & -2.87 & 2.8 & 26 & -4.09 & 3.57 & 29 & $27.3 \%$ & $0.37[-0.16,0.91]$ & & 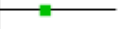 & \\
\hline Lin 2017 & 19.7 & 3.4 & 40 & 17.2 & 3.8 & 40 & $38.2 \%$ & $0.69[0.24,1.14]$ & & & \\
\hline Total $(95 \% \mathrm{Cl})$ & & & 93 & & & 118 & $100.0 \%$ & $0.52[0.24,0.80]$ & & & \\
\hline $\begin{array}{l}\text { Heterogeneity: } \mathrm{Tau}^{2}= \\
\text { Test for overall effect }\end{array}$ & $\begin{array}{l}0.00 ; \\
Z=3.6\end{array}$ & $\begin{array}{l}\mathrm{hi}^{2}=0 \\
5(\mathrm{P}=\end{array}$ & $\begin{array}{l}.90, d f \\
0.0003\end{array}$ & $=2$ & $=0.6$ & 4); $1^{2}=$ & & & $\begin{array}{cc}-1 & + \\
\text { Favours control } & 0\end{array}$ & Favours is & $\begin{array}{l}1 \\
\text { ervention }\end{array}$ \\
\hline
\end{tabular}

FIGURE 5 Meta-analyses comparing the intervention effects on Manual Dexterity. 
TABLE 1 Risk of Bias Checklist ${ }^{31}$

\begin{tabular}{|c|c|}
\hline Item & Description \\
\hline A & $\begin{array}{l}\text { Key baseline characteristics are presented separately for treatment groups (age, gender and fine motor } \\
\text { skill outcome measure), baseline outcomes were statistically tested and results of test were provided }\end{array}$ \\
\hline B & $\begin{array}{l}\text { Randomization (generation of allocation sequence, allocation concealment and implementation) clearly } \\
\text { described and adequately completed }\end{array}$ \\
\hline C & Validated measures of fine motor skill development used (validation in same aged group/ or cited) \\
\hline D & $\begin{array}{l}\text { Blinded outcome assessment (positive when those responsible for assessing fine motor development } \\
\text { were blinded to group allocation of individual participants) }\end{array}$ \\
\hline $\mathbf{E}$ & $\begin{array}{l}\text { Drop out described, with a } \leq 20 \% \text { dropout for studies with }<6 \text {-months follow up or } \leq 30 \% \text { for } \geq 6 \text { - } \\
\text { months follow up. }\end{array}$ \\
\hline $\mathbf{F}$ & Power calculation reported for main fine motor development outcome. \\
\hline G & $\begin{array}{l}\text { Intention -to-treat analyses of fine motor development outcome, participants analyzed in group they } \\
\text { were originally allocated to and participants were not excluded from analyses because of } \\
\text { noncompliance to treatment or because of missing data }\end{array}$ \\
\hline H & $\begin{array}{l}\text { Covariates accounted for in analyses (e.g., baseline score, group/ cluster for cluster RCT's, and other } \\
\text { relevant covariates when appropriate such as age or gender) }\end{array}$ \\
\hline I & $\begin{array}{l}\text { Summary results for each group and/or estimated effect size (difference between groups) and its } \\
\text { precision (e.g., } 95 \% \mathrm{CI})\end{array}$ \\
\hline
\end{tabular}


TABLE 4 Measurements of Fine Motor Development

\begin{tabular}{|c|c|c|c|c|c|c|c|}
\hline Assessment Tool & Description & $\begin{array}{l}\text { Age range } \\
\text { (years) }\end{array}$ & Assessors & $\begin{array}{l}\text { Outcome } \\
\text { measure }\end{array}$ & $\begin{array}{l}\text { Skills tested related to Fine } \\
\text { Motor }\end{array}$ & Reliability and validity & Used by \\
\hline $\begin{array}{l}\text { British Ability } \\
\text { Scales, 2nd edition } \\
\text { (BAS II), copying } \\
\text { subtest }\end{array}$ & $\begin{array}{l}\text { is used to assess the children's fine motor } \\
\text { skills. }\end{array}$ & & $\begin{array}{l}\text { the author, } \\
\text { and a } \\
\text { secondary, } \\
\text { "blind" } \\
\text { assessor }\end{array}$ & Fine Motor & subtest Copying & N/A & Brown (2010) \\
\hline $\begin{array}{l}\text { Bruininks-Oseretsky } \\
\text { Test of Motor } \\
\text { Proficiency, 2nd } \\
\text { edition (BOT-2) }\end{array}$ & $\begin{array}{l}\text { is a norm-referenced standardized motor- } \\
\text { assessment and was designed to assess } \\
\text { children's motor development by } \\
\text { measuring their gross- and fine-motor } \\
\text { skills. BOT-2 has two versions, a Long } \\
\text { and Short Form, both can be used to } \\
\text { examine the participants' fine motor } \\
\text { performance. }\end{array}$ & 4 to 21 & $\begin{array}{l}\text { (registered) } \\
\text { Occupational } \\
\text { Therapists or } \\
\text { Occupational } \\
\text { Therapy } \\
\text { graduate } \\
\text { students, } \\
\text { who had } \\
\text { been trained } \\
\text { in the } \\
\text { assessments }\end{array}$ & $\begin{array}{l}\text { Fine Motor } \\
\text { Scale }\end{array}$ & $\begin{array}{l}\text { fine motor precision (e.g., } \\
\text { cutting out a circle, } \\
\text { connecting dots), fine motor } \\
\text { integration (e.g., copying a } \\
\text { star, copying a square), } \\
\text { manual dexterity (e.g., } \\
\text { transferring pennies, sorting } \\
\text { cards, stringing blocks), and } \\
\text { upper limb coordination (e.g., } \\
\text { throwing a ball at a target, } \\
\text { catching a tossed ball) }\end{array}$ & $\begin{array}{l}\text { Fine Manual Control: } \\
\text { Internal consistency = } 0.87 \text { ( } 4 \text {-yr-olds); } \\
\text { Internal consistency }=0.86 \text { (5-yr-olds); } \\
\text { Test-retest }=0.81 \text { (4- to } 7 \text {-yr-olds) } \\
\text { The Manual Coordination subscale: } \\
\text { test-retest range }=0.62-0.79 \text {; inter- } \\
\text { rater }=0.98 \\
\text { Quote: "the short form is generally a } \\
\text { reliable and valid measure of general } \\
\text { motor ability." }\end{array}$ & $\begin{array}{l}\text { Lin et al (2017), } \\
\text { Lust et al (2011), } \\
\text { Ohl et al (2013), } \\
\text { Piek et al (2014), } \\
\text { Ratzon et al (2007) }\end{array}$ \\
\hline $\begin{array}{l}\text { Denver } \\
\text { Developmental } \\
\text { Screening Test, 2nd } \\
\text { edition (DDST II) }\end{array}$ & $\begin{array}{l}\text { is a widely used tool for evaluative } \\
\text { screening of fine and gross motor } \\
\text { development in toddlers. The DDTS } \\
\text { subscales included: personal/social, } \\
\text { language, fine motor skills and gross } \\
\text { motor skills. }\end{array}$ & 0 to 6 & $\begin{array}{l}\text { mother, } \\
\text { fathers or } \\
\text { babysitters } \\
\text { (closely } \\
\text { related) }\end{array}$ & Fine Motor & N/A & $\begin{array}{l}\text { Test re-test range }=0.90-0.97 \\
\text { Interrater range }=0.80-0.95\end{array}$ & $\begin{array}{l}\text { Ulutas et al (2016), } \\
\text { Zoghi et al (2015) }\end{array}$ \\
\hline $\begin{array}{l}\text { Developmental Test } \\
\text { of Visual Perception, } \\
\text { 2nd edition (DTVP- } \\
\text { 2), Korean 2nd } \\
\text { edition (K-DTVP-2) }\end{array}$ & $\begin{array}{l}\text { is a well-constructed and effective } \\
\text { psychometric test frequently used by } \\
\text { paediatric occupational therapists to } \\
\text { identify the visual-perceptual and motor } \\
\text { performance of children. }\end{array}$ & 4 to 8 & $\begin{array}{l}\text { Authors, } \\
\text { Occupational } \\
\text { Therapists or } \\
\text { a trained } \\
\text { research } \\
\text { team }\end{array}$ & $\begin{array}{l}\text { Visual } \\
\text { Motor } \\
\text { Integration } \\
\text { and Visual } \\
\text { Perception }\end{array}$ & $\begin{array}{l}\text { visual motor Integration } \\
\text { performance: eye-hand } \\
\text { coordination, copying, spatial } \\
\text { relationships, and visual-- } \\
\text { motor speed }\end{array}$ & $\begin{array}{l}\text { Test-retest range }=0.71-0.86 ; \text { Test- } \\
\text { retest total }=0.96 ; \text { Interrater }=0.98\end{array}$ & $\begin{array}{l}\text { Ratzon et al (2007), } \\
\text { Ratzon et al (2009) A, } \\
\text { Ratzon et al (2009) B, } \\
\text { Lahav et al (2008), } \\
\text { Case- Smith (2000), } \\
\text { Jeon et al (2016) }\end{array}$ \\
\hline Flag Posting Test & $\begin{array}{l}\text { involves an apparatus consisting of a } \\
\text { solid hardwood tray covered with clay in } \\
\text { which there are } 12 \text { pinholes to post flags. }\end{array}$ & N/A & $\begin{array}{l}\text { Single } \\
\text { trained test } \\
\text { administrator }\end{array}$ & $\begin{array}{l}\text { Fine Motor } \\
\text { control }\end{array}$ & $\begin{array}{l}\text { accuracy, speed, and hand } \\
\text { dominance. }\end{array}$ & $\begin{array}{l}\text { Interrater FM Speed }=0.995,95 \% \\
\text { confidence interval }(\mathrm{CI})[.90,1.00] \\
\text { Interrater FM accuracy }=0.884,95 \% \mathrm{CI} \\
{[.65, .94]}\end{array}$ & Bhatia et al (2015) \\
\hline
\end{tabular}


TABLE 4 Continued

\begin{tabular}{|c|c|c|c|c|c|c|c|}
\hline Assessment Tool & Description & $\begin{array}{l}\text { Age range } \\
\text { (years) }\end{array}$ & Assessors & $\begin{array}{l}\text { Outcome } \\
\text { measure }\end{array}$ & $\begin{array}{l}\text { Skills tested related to Fine } \\
\text { Motor }\end{array}$ & Reliability and validity & Used by \\
\hline $\begin{array}{l}\text { Le Roux's Group } \\
\text { Test }\end{array}$ & $\begin{array}{l}\text { determines all aspects of learning } \\
\text { readiness. }\end{array}$ & 5 to 7 & N/A & $\begin{array}{l}\text { Fine Motor } \\
\text { ability and } \\
\text { Visual } \\
\text { Perception }\end{array}$ & $\mathrm{N} / \mathrm{A}$ & $\begin{array}{l}\text { Quote: "is used in South Africa for } \\
\text { many ECD research Studies as } \\
\text { measuring instrument because of the } \\
\text { validity and reliability of this registered } \\
\text { test" }\end{array}$ & Erasmus et al (2015) \\
\hline $\begin{array}{l}\text { Lista de cotejo } \\
\text { (checklist) }\end{array}$ & $\begin{array}{l}\text { is a direct observation checklist, that is, } \\
\text { the progressive development of } \\
\text { increasingly complex skills for more } \\
\text { proficient tasks of daily living and } \\
\text { playing. }\end{array}$ & 0.5 to 4 & $\begin{array}{l}\text { trained } \\
\text { fieldworkers }\end{array}$ & Fine Motor & N/A & $\begin{array}{l}\text { Quote: "used the nationally validated } \\
\text { ECD evaluation instrument, created for } \\
\text { and used by the PNWW. The instrument } \\
\text { has been originally assessed for content } \\
\text { validity by a PNWW-expert panel for } \\
\text { each specific developmental area." }\end{array}$ & Hartinger et al (2016) \\
\hline $\begin{array}{l}\text { Metropolitan } \\
\text { Readiness test-level } \\
1 \text {, copying test }\end{array}$ & $\begin{array}{l}\text { is a name copying task as an indication } \\
\text { of eye-hand coordination, a visual } \\
\text { perceptual-motor development skill. }\end{array}$ & & one person & Fine Motor & name writing & Reliability $=0.88$ & Gabbard (1978) \\
\hline $\begin{array}{l}\text { Mullen Scales of } \\
\text { Early Learning }\end{array}$ & $\begin{array}{l}\text { is a widely used individually } \\
\text { administered, comprehensive measure of } \\
\text { cognitive functioning. It assesses the } \\
\text { child's visual, receptive language, } \\
\text { expressive language and motor skills. } \\
\text { The Visual Reception and Fine Motor } \\
\text { scales reflect cognitive abilities that are } \\
\text { important for a smooth transition to a } \\
\text { school setting. The Fine Motor scale } \\
\text { measures visual-motor ability. }\end{array}$ & 0 to 5.7 & $\begin{array}{l}\text { trained } \\
\text { nurses }\end{array}$ & $\begin{array}{l}\text { Fine Motor } \\
\text { Scale }\end{array}$ & $\begin{array}{l}\text { Visual organization and } \\
\text { discrimination, Fine Motor } \\
\text { control and writing readiness. }\end{array}$ & N/A & Janssens et al (2013) \\
\hline $\begin{array}{l}\text { Peabody } \\
\text { Developmental } \\
\text { Motor Scales, Fine } \\
\text { Motor 1st edition } \\
\text { (PDMS-FM), 2nd } \\
\text { edition (PDMS-2) }\end{array}$ & $\begin{array}{l}\text { is a norm-referenced standardized test } \\
\text { measures hand use, eye-hand } \\
\text { coordination and manual dexterity using } \\
\text { typical preschool activities. }\end{array}$ & 0 to 5 & $\begin{array}{l}\text { trained } \\
\text { research } \\
\text { team }\end{array}$ & $\begin{array}{l}\text { Fine Motor } \\
\text { scale }\end{array}$ & $\begin{array}{l}\text { Grasping and Visual-Motor } \\
\text { Integration evaluate } \\
\text { children's fine motor skill } \\
\text { performance (e.g. cutting, } \\
\text { building blocks, lacing) }\end{array}$ & $\begin{array}{l}\text { 1st edition: } \\
\text { Test retest }=0.80 ; \text { Interrater }=0.94 \\
\text { 2nd edition: } \\
\text { Test- retest }=0.93) \text {; Interrater } 0.98 ;\end{array}$ & $\begin{array}{l}\text { Bazyk et al (2009), } \\
\text { Case- Smith (1999), } \\
\text { Hamilton et al (2017), } \\
\text { Pienaar et al (2011), }\end{array}$ \\
\hline
\end{tabular}


TABLE 4 Continued

\begin{tabular}{|c|c|c|c|c|}
\hline Assessment Tool & Description & $\begin{array}{l}\text { Age range } \\
\text { (years) }\end{array}$ & Assessors & $\begin{array}{l}\text { Outcome } \\
\text { measure }\end{array}$ \\
\hline $\begin{array}{l}\text { The Beery- } \\
\text { Buktenica } \\
\text { Developmental test } \\
\text { of Visual-Motor } \\
\text { integration; 3rd, 4th, } \\
\text { 5th and 6th edition } \\
\text { (The Beery VMI) }\end{array}$ & $\begin{array}{l}\text { a norm-referenced standardized test for } \\
\text { children requires the child to draw a } \\
\text { developmental sequence of } 24 \text { geometric } \\
\text { forms using paper and pencil. The test } \\
\text { measures Visual motor skills by } \\
\text { examining child's drawings that attempt } \\
\text { to replicate the geometric stimulus. }\end{array}$ & $\begin{array}{l}3 \text { to } 17 \\
\text { (3th), } \\
2 \text { to } 18 \text { ( } 4 \text { th } \\
\text { and } 5 \text { th), } \\
\text { all ages } \\
\text { (6th) }\end{array}$ & $\begin{array}{l}\text { Authors, } \\
\text { trained } \\
\text { research } \\
\text { team, } \\
\text { registered } \\
\text { Occupational } \\
\text { Therapists } \\
\text { and trained } \\
\text { assessors }\end{array}$ & $\begin{array}{l}\text { Visual } \\
\text { Motor } \\
\text { Integration, } \\
\text { Visual } \\
\text { Perception } \\
\text { and Motor } \\
\text { Coordination }\end{array}$ \\
\hline
\end{tabular}

The Movement

Assessment Battery

of Children, 1st

edition (M-ABC),

2nd edition (M-

ABC-2)

is a norm-referenced measure that

evaluates manual dexterity, ball and

balance skills in children.
Vineland Adaptive Behavior ScalesClassroom Edition (VABS-C)

\section{Visual-motor}

sequential subtest of the Illinois Test of

Psycholinguistic

Abilities (ITPA) measures adaptive function in the areas of communication, daily living skills, socialization, and motor skills for children.

a visual analogue of the auditory subtest using pictures and geometric forms used as a test of visual attention.
4 to 12

trained

Manual

Dexterity

level of motor proficiency

tested related to Fine

writing

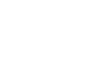

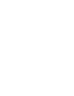

shape formatting, name

Reliability and validity

3rd edition:

Test-retest $=0.62-0.84 ;$ Interrater $=$

0.97 ; Split-half $=0.74$

4th edition:

Test-retest $=0.87$ Interrater $=0.94$

5th edition:

Test-retest $=0.87-0.89) ;$ Interrater $=$ $0.92-0.94 ;$ Internal $=0.88-0.92$ ) and acceptable construct validity

6th edition:

Item separation $=1.00$; person

separation $=0.96 ;$ Interscorer $=0.93$.

1st edition:

Minimum Test-retest $=0.75$; minimum Interrater 0.70

Concurrent validity $=80 \%$ agreement

between the $\mathrm{M}-\mathrm{ABC}$ and the

Bruininks-Oseretsky Test of Motor

Performance

2nd edition:

Test-retest range $=0.86-0.91$

3 to 12 Teacher Fine Motor The fine motor skills subscale includes 13 items such as "[the child] cuts along a line with scissors fairly accurately."

Quote: "The VABS-C was normed on a national sample of almost 3,000 children and has high reliability and content, construct, and criterion validity."

Visual N/A

N/A

McCormick et al (1971)

Used by

Axford et al (2018),

Bazyk et al (2009),

Dankert et al (2003),

Dibek (2012),

Golos et al (2011),

Golos et al (2013),

Howe et al (2013),

Lahav et al (2008),

Ohl et al (2013),

Pfeiffer et al (2015),

Ratzon et al (2007),

Ratzon et al (2009) A,

Ratzon et al (2009) B,

Tzuriel et al (1992)

Golos et al (2011),

Golos et al (2013),

Piek et al (2014)

Bayona et al (2006)

Motor 
Supplemental Digital Content 1

\begin{tabular}{|c|c|c|c|c|c|c|c|}
\hline $\begin{array}{l}\text { Reference (author, } \\
\text { year, country) }\end{array}$ & $\begin{array}{l}\text { Design and } \\
\text { Setting }\end{array}$ & Sample & $\begin{array}{l}\text { Intervention } \\
\text { Length (total min) }\end{array}$ & $\begin{array}{l}\text { Intervention Groups and } \\
\text { Facilitator }\end{array}$ & Intervention Content & $\begin{array}{l}\text { Fine Motor Measure } \\
\text { and data collection }\end{array}$ & Retention and Results \\
\hline $\begin{array}{l}\text { Axford et al (2018) } \\
\text { Australia }\end{array}$ & $\begin{array}{l}\text { Two-group non- } \\
\text { randomised } \\
\text { controlled trial, } 2 \\
\text { pre-primary } \\
\text { classrooms }\end{array}$ & $\begin{array}{l}\text { INT: } n=28 \\
\text { CON: } n=25 \\
\text { Overall aged } 56-70 \\
\text { mo) }\end{array}$ & $\begin{array}{l}9 \text { weeks ( } 1350 \\
\text { min) }\end{array}$ & $\begin{array}{l}\text { INT: iPad applications } \\
\text { CON: table top and fine motor } \\
\text { activities } \\
\text { Facilitator: } \\
\text { INT: Teachers } \\
\text { CON: Teachers }\end{array}$ & $\begin{array}{l}\text { INT: } 30 \text { min daily where children } \\
\text { could select out of three specific } \\
\text { Apps, specially selected by teacher. } \\
\text { CON: Activities included threading, } \\
\text { cutting, jigsaw, form-board puzzles } \\
\text { and building with blocks, which } \\
\text { formed normal part of school } \\
\text { program. }\end{array}$ & $\begin{array}{l}\text { The Beery-Buktenica } \\
\text { Developmental test of } \\
\text { Visual-Motor } \\
\text { integration, } 6^{\text {th }} \text { edition } \\
\text { (The Beery VMI) } \\
\text { Data Collection: } 0,9 \\
\text { wks }\end{array}$ & $\begin{array}{l}\text { RET: } 53 / 54(98 \%) \\
\text { INT > CON: MC } \\
\text { (standard score: } \mathrm{p}=.02 ; \\
d=0.93 \text {; age equivalent } \\
\text { score: } \mathrm{p}=.004 ; d=1.08) \\
\text { INT }=\text { CON: increase } \\
\text { VMI }(\mathrm{p}=.001 ; d=066)\end{array}$ \\
\hline $\begin{array}{l}\text { Bayona et al (2006) } \\
\text { Canada }\end{array}$ & $\begin{array}{l}\text { Quasi-experiment } \\
\text { (one group), } 2 \\
\text { school boards }\end{array}$ & $\begin{array}{l}{ }^{\mathrm{a}} \mathrm{INT}: n=23 \\
17 \% \text { girls; mean age } \\
76 \text { mo, aged } 5-8 \mathrm{y}\end{array}$ & 5 mo (unclear) & $\begin{array}{l}\text { INT: School Health Support } \\
\text { Services (SHSS) program } \\
\text { CON: N/A. } \\
\text { Facilitator: } \\
\text { INT: Occupational Therapists } \\
\text { CON: N/A }\end{array}$ & $\begin{array}{l}\text { INT: shifted from } 18-22 \text { to } 5 \text { - } 10 \\
\text { consultant visits throughout the } \\
\text { school year, depending on child's } \\
\text { needs }\end{array}$ & $\begin{array}{l}\text { Vineland Adaptive } \\
\text { Behavior Scales- } \\
\text { Classroom Edition } \\
\text { (VABS-C) } \\
\text { Data Collection: } 0,5 \\
\text { mo }\end{array}$ & $\begin{array}{l}\text { RET: } 23 / 35(66 \%) \\
22 / 23(96 \%) \text { for FM } \\
\text { INT = CON: FM } \\
(d=0.25)\end{array}$ \\
\hline $\begin{array}{l}\text { Bazyk et al (2009) } \\
\text { United States }\end{array}$ & $\begin{array}{l}\text { Single-group } \\
\text { pretest-posttest } \\
\text { descriptive } \\
\text { design, } 2 \\
\text { integrated } \\
\text { kindergarten } \\
\text { classrooms }\end{array}$ & $\begin{array}{l}\text { INT: } n=25 \\
\text { mean age } 71.5 \mathrm{mo}, \\
\text { aged } 60-83 \mathrm{mo}\end{array}$ & $\begin{array}{l}7 \text { mo (mean } 567 \\
\text { min; range } 335- \\
885 \text { min per child) }\end{array}$ & $\begin{array}{l}\text { INT: Occupational Therapy } \\
\text { Services } \\
\text { CON: N/A. } \\
\text { Facilitator: } \\
\text { INT: Occupational Therapists } \\
\text { and Teachers } \\
\text { CON: N/A }\end{array}$ & $\begin{array}{l}\text { INT: } 2 \text { days per week of Indirect } \\
\text { (eg. learning about the curriculum, } \\
\text { making classroom observations, } \\
\text { engaging in collaborative } \\
\text { consultation with teachers, parents, } \\
\text { ant other service providers, and } \\
\text { undertaking preparation activities) } \\
\text { and direct services (eg group and } \\
\text { individual assessment and } \\
\text { intervention fully embedded in the } \\
\text { classroom curriculum) }\end{array}$ & $\begin{array}{l}\text { Peabody Developmental } \\
\text { Motor Scales, } 2^{\text {nd }} \\
\text { edition (PDMS-2), The } \\
\text { Beery-Buktenica } \\
\text { Developmental test of } \\
\text { Visual-Motor } \\
\text { integration, } 4^{\text {th }} \text { edition } \\
\text { (The Beery VMI) } \\
\text { Data collection: } 0,7 \text { mo }\end{array}$ & $\begin{array}{l}\text { RET: } 100 \% \\
\text { INT > CON: PDMS- } 2 \\
\text { FM ( }=.021 ; d=0.202) \\
\text { VMI }(p=.023 ; d=0.198) ;\end{array}$ \\
\hline $\begin{array}{l}\text { Bhatia et al (2015) } \\
\text { United States }\end{array}$ & $\begin{array}{l}\text { Quasi-experiment, } \\
4 \text { private } \\
\text { Montessori school } \\
\text { and } 1 \text { public } \\
\text { elementary school }\end{array}$ & $\begin{array}{l}\text { INT: } n=50 \\
\text { CON: } n=50 \\
\text { Overall aged } 5 \mathrm{y}\end{array}$ & $8 \mathrm{mo}(31500 \mathrm{~min})$ & $\begin{array}{l}\text { INT: Practical life activities } \\
\text { CON: Traditional kindergarten } \\
\text { curriculum } \\
\text { Facilitator: } \\
\text { INT: Teachers } \\
\text { CON: Teachers }\end{array}$ & $\begin{array}{l}\text { INT: } 180 \text { min daily where children } \\
\text { could choose among } 6 \text { types of } \\
\text { activities, including practical life } \\
\text { activities. } \\
\text { CON: Traditional kindergarten } \\
\text { activities }\end{array}$ & $\begin{array}{l}\text { Flag Posting Test } \\
\text { Data collection: } 0,8 \mathrm{mo}\end{array}$ & $\begin{array}{l}\text { RET: } 100 \% \\
\text { INT }>\text { CON: FM } \\
\text { accuracy }(\mathrm{p}<.001) ; \text { FM } \\
\text { speed }(\mathrm{p}=.003) .\end{array}$ \\
\hline
\end{tabular}




\begin{tabular}{|c|c|c|c|c|c|c|c|}
\hline \multicolumn{8}{|c|}{ TABLE 2 Continued } \\
\hline $\begin{array}{l}\text { Reference (author, } \\
\text { year, country) }\end{array}$ & $\begin{array}{l}\text { Design and } \\
\text { Setting }\end{array}$ & Sample & $\begin{array}{l}\text { Intervention } \\
\text { Length (total min) }\end{array}$ & $\begin{array}{l}\text { Intervention Groups and } \\
\text { Facilitator }\end{array}$ & Intervention Content & $\begin{array}{l}\text { Fine Motor Measure } \\
\text { and data collection }\end{array}$ & Retention and Results \\
\hline $\begin{array}{l}\text { Brown (2010) } \\
\text { England }\end{array}$ & $\begin{array}{l}\text { Repeated } \\
\text { measures design, } \\
2 \text { primary schools }\end{array}$ & $\begin{array}{l}\text { INT: } n=32 \\
40.6 \% \text { girls; mean } \\
\text { age } 69.0 \text { mo } \\
\text { CON: } n=33 \\
57.3 \% \text { girls; mean } \\
\text { age } 72.5 \text { mo } \\
\text { Overall aged } 4-5 \text { y }\end{array}$ & $5 \mathrm{mo}(1650 \mathrm{~min})$ & $\begin{array}{l}\text { INT: Primary Movement } \\
\text { programme. } \\
\text { CON: Brain Gym programme } \\
\text { Facilitator: } \\
\text { INT: Teachers } \\
\text { CON: Teachers }\end{array}$ & $\begin{array}{l}\text { INT: } 15 \text { min a day of acting out } \\
\text { song movements. } \\
\text { CON: similar procedure with the } \\
\text { Brain Gym Programme }\end{array}$ & $\begin{array}{l}\text { British Ability Scales, } \\
2^{\text {nd }} \text { edition (BAS II); } \\
\text { copying (FM) part only } \\
\text { Data Collection: } 0,5 \\
\text { mo }\end{array}$ & $\begin{array}{l}\text { RET: } 100 \% \\
\text { INT }>\text { CON: FM } \\
(\mathrm{p}<.001 ; d=0.71)\end{array}$ \\
\hline $\begin{array}{l}\text { Case- Smith (2000) } \\
\text { United States }\end{array}$ & $\begin{array}{l}\text { Descriptive } \\
\text { design (single } \\
\text { group), public } \\
\text { schools }\end{array}$ & $\begin{array}{l}\text { INT: } n=44 \\
34 \% \text { girls; mean age } \\
56.53 \text { mo, aged } 44- \\
72 \text { mo }\end{array}$ & $\begin{array}{l}8 \mathrm{mo}(825 \mathrm{~min} \\
\text { range } 408-1824)\end{array}$ & $\begin{array}{l}\text { INT: Occupational Therapy } \\
\text { sessions } \\
\text { CON: N/A. } \\
\text { Facilitator: } \\
\text { INT: Occupational Therapists } \\
\text { CON: N/A }\end{array}$ & $\begin{array}{l}\text { INT: sensory integration, motor/ } \\
\text { manipulation, self-care and } \\
\text { play/peer interaction activities. } \\
\text { Group, individual sessions and } \\
\text { teachers consulting }\end{array}$ & $\begin{array}{l}\text { Peabody Developmental } \\
\text { Motor Scales-Fine } \\
\text { Motor, } 1^{\text {st }} \text { edition } \\
\text { (PDMS-FM); } \\
\text { Developmental Test of } \\
\text { Visual Perception, } 2^{\text {nd }} \\
\text { edition (DTVP-2); } \\
\text { Data Collection: } 0,8 \\
\text { mo }\end{array}$ & $\begin{array}{l}\text { RET: } 41 / 44(93 \%) \text { for } \\
\text { PDMS-FM, } 43 / 44 \\
(98 \%) \text { for DTVP-VMI } \\
\text { INT }>\text { : PDMS-FM } \\
(d=1.87) \text {; DTVP-VMI } \\
(d=1.83)\end{array}$ \\
\hline $\begin{array}{l}\text { Dankert et al (2003) } \\
\text { United States }\end{array}$ & $\begin{array}{l}\text { Quasi-experiment, } \\
\text { one school }\end{array}$ & $\begin{array}{l}\text { INT: } n=16 \\
69 \% \text { girls; mean age } \\
52.63 \pm 4.10 \text { mo } \\
\text { CON: } n=15 \\
47 \% \text { girls; mean age } \\
53.4 \pm 2.88 \text { mo } \\
\text { Overall aged } 3-6 y\end{array}$ & $8 \mathrm{mo}(1050 \mathrm{~min})$ & $\begin{array}{l}\text { INT: Direct occupational } \\
\text { therapy services. } \\
\text { CON: No treatment } \\
\text { Facilitator: } \\
\text { INT: Occupational Therapist } \\
\text { (author) } \\
\text { CON: N/A }\end{array}$ & $\begin{array}{l}\text { INT: } 30 \text { min per week including } \\
\text { fine motor activities, such as art and } \\
\text { crafts, finger plays and small } \\
\text { manipulatives; gross motor } \\
\text { activities such as obstacle course, } \\
\text { music, dancing; and visual-motor } \\
\text { and visual perception activities such } \\
\text { as drawing, cutting and assembly. }\end{array}$ & $\begin{array}{l}\text { The Beery-Buktenica } \\
\text { Developmental test of } \\
\text { Visual-Motor } \\
\text { integration, } 3^{\text {rd }} \text { edition } \\
\text { (The Beery VMI) } \\
\text { Data Collection: } 0,8 \\
\text { mo }\end{array}$ & $\begin{array}{l}\text { RET: unclear } \\
\text { INT }=\mathrm{CON}\end{array}$ \\
\hline $\begin{array}{l}\text { Dibek (2012) } \\
\text { Turkey }\end{array}$ & $\begin{array}{l}\text { Quasi-experiment, } \\
4 \text { classrooms from } \\
\text { a state school }\end{array}$ & $\begin{array}{l}\text { a INT: } n=17 \\
47 \% \text { girls } \\
\text { CON: } n=16 \\
31 \% \text { girls } \\
\text { Overall aged } 60-69 \\
\text { mo }\end{array}$ & $\begin{array}{l}10 \text { wks }(800-950 \\
\min )\end{array}$ & $\begin{array}{l}\text { INT: Visual Motor Ability } \\
\text { Enhancement Program } \\
\text { (VMAEP) } \\
\text { CON: Regular education } \\
\text { Facilitator: } \\
\text { INT: Unclear } \\
\text { CON: N/A }\end{array}$ & $\begin{array}{l}\text { INT: } 3 \text { days per week; day } 1 \text { story } \\
\text { book was read ( } 15-20 \mathrm{~min}) \text {, day } 2 \\
\text { includes story activities ( } 40-45 \mathrm{~min}) \text {, } \\
\text { day } 3 \text { use of } 3 \mathrm{D} \text { and } 2 \mathrm{D} \text { materials } \\
\text { (25-30min) }\end{array}$ & $\begin{array}{l}\text { The Beery-Buktenica } \\
\text { Developmental test of } \\
\text { Visual-Motor } \\
\text { integration, } 5^{\text {th }} \text { edition } \\
\text { (The Beery VMI) } \\
\text { Data collection: } 0,10 \\
\text { wks }\end{array}$ & $\begin{array}{l}\text { RET: } 32 / 38(84 \%) \\
\text { INT > CON: VMI } \\
(\mathrm{p}<.001) ; \mathrm{VP}(\mathrm{p}=.01)\end{array}$ \\
\hline
\end{tabular}




\begin{tabular}{|c|c|c|c|c|c|c|c|}
\hline $\begin{array}{l}\text { Reference (author, } \\
\text { year, country) }\end{array}$ & $\begin{array}{l}\text { Design and } \\
\text { Setting }\end{array}$ & Sample & $\begin{array}{l}\text { Intervention } \\
\text { Length (total min) }\end{array}$ & $\begin{array}{l}\text { Intervention Groups and } \\
\text { Facilitator }\end{array}$ & Intervention Content & $\begin{array}{l}\text { Fine Motor Measure } \\
\text { and data collection }\end{array}$ & Retention and Results \\
\hline $\begin{array}{l}\text { Erasmus et al } \\
\text { (2015) South Africa }\end{array}$ & $\begin{array}{l}\text { Mixed-method } \\
\text { research; quasi- } \\
\text { experiment, } 2 \\
\text { primary schools }\end{array}$ & $\begin{array}{l}\text { INT: } n=21 \\
52.4 \% \text { girls } \\
\text { CON: } n=27 \\
59.3 \% \text { girls } \\
\text { Overall aged } 5-5.5 \\
\text { y }\end{array}$ & $\begin{array}{l}10 \text { wks }(1200 \\
\min )\end{array}$ & $\begin{array}{l}\text { INT: Perceptual-Motor } \\
\text { Intervention Programme } \\
\text { CON: Unclear } \\
\text { Facilitator: } \\
\text { INT: Researchers } \\
\text { CON: Unclear }\end{array}$ & $\begin{array}{l}\text { INT: } 3 \text { times } 40 \text { min per week } \\
\text { where } 20 \text { min was spending on } \\
\text { Gross motor, } 10 \text { min on Fine motor } \\
\text { and } 10 \text { min on Perceptual activities }\end{array}$ & $\begin{array}{l}\text { Le Roux's Group Test } \\
\text { Data Collection: 0, } 10 \\
\text { wks }\end{array}$ & $\begin{array}{l}\text { RET: } 100 \% \\
\text { INT < CON: FM } \\
(\mathrm{p}<.0001 ; d=0.32) \\
\text { INT > CON: VP } \\
(\mathrm{p}=0.0321 ; d=0.58)\end{array}$ \\
\hline $\begin{array}{l}\text { Gabbard (1978) } \\
\text { United States }\end{array}$ & $\mathrm{RCT}$ & $\begin{array}{l}\text { INT: } n=52 \\
\text { CON: } n=52 \\
\text { Overall mean age } \\
5.3 \mathrm{y}\end{array}$ & 10 wks (900 min) & $\begin{array}{l}\text { INT: eye-hand coordination } \\
\text { CON: Free-play activities } \\
\text { Facilitator: } \\
\text { INT: Unclear } \\
\text { CON: N/A }\end{array}$ & $\begin{array}{l}\text { INT: } 3 \text { times } 30 \text { min per week with } \\
\text { eye-hand coordination activities and } \\
2 \text { days free play }\end{array}$ & $\begin{array}{l}\text { Metropolitan Readiness } \\
\text { test-level 1, copying test } \\
\text { Data Collection: } 0,10 \\
\text { wks }\end{array}$ & $\begin{array}{l}\text { RET: } 100 \% \\
\text { INT }>\text { CON: FM } \\
(\mathrm{p}<.01)\end{array}$ \\
\hline $\begin{array}{l}\text { Golos et al (2011) } \\
\text { Israel }\end{array}$ & $\begin{array}{l}\text { pre-post two } \\
\text { group } \\
\text { longitudinal; } \\
\text { RCT, } 3 \text { Israeli } \\
\text { ultraorthodox } \\
\text { educational } \\
\text { settings }\end{array}$ & $\begin{array}{l}\text { INT: } n=31 \\
\text { mean age } 51.15 \pm \\
3.98 \text { mo } \\
\text { CON: } n=54 \\
\text { mean age } 52.00 \pm \\
4.16 \text { mo } \\
\text { Overall } 0 \% \text { girls }\end{array}$ & $8 \mathrm{mo}(1050 \mathrm{~min})$ & $\begin{array}{l}\text { INT: Monitoring model } \\
\text { CON: Unclear } \\
\text { Facilitator: } \\
\text { INT: Teachers } \\
\text { CON: Unclear }\end{array}$ & $\begin{array}{l}\text { INT: } 30 \text { min per week where small- } \\
\text { groups practiced manual dexterity, } \\
\text { gross motor skills, graphomotor } \\
\text { skills and cognitive skills; teacher } \\
\text { and occupation therapist } \\
\text { consultation and monitoring }\end{array}$ & $\begin{array}{l}\text { The Beery-Buktenica } \\
\text { Developmental test of } \\
\text { Visual-Motor } \\
\text { integration, } 5^{\text {th }} \text { edition } \\
\text { (The Beery VMI); The } \\
\text { Movement Assessment } \\
\text { Battery of Children (M- } \\
\text { ABC), } 1^{\text {st }} \text { edition } \\
\text { Data Collection: } 0,8 \\
\text { mo }\end{array}$ & $\begin{array}{l}\text { RET: } 27 / 31(87 \%) \text { INT, } \\
\text { 49/54 (91\%) CON } \\
\text { INT > CON: VMI } \\
(\mathrm{p}<.000) ; \mathrm{MD}(\mathrm{p}<.000)\end{array}$ \\
\hline $\begin{array}{l}\text { Golos et al (2013) } \\
\text { Israel }\end{array}$ & $\begin{array}{l}\text { pre-post two } \\
\text { group } \\
\text { longitudinal; } \\
\text { quasi-experiment, } \\
2 \text { Israeli } \\
\text { ultraorthodox } \\
\text { educational } \\
\text { settings }\end{array}$ & $\begin{array}{l}\text { INT } 1: n=28 \\
\text { preschool mean age } \\
50.61 \pm 4.05 \text { mo \& } \\
\text { kindergarten mean } \\
\text { age } 60.43 \pm 3.86 \text { mo } \\
\text { INT } 2: n=30 \\
\text { mean age } 65.07 \\
\pm 4.49 \text { mo } \\
\text { Overall } 0 \% \text { girls }\end{array}$ & $\begin{array}{l}8 \text { and } 16 \text { mo } \\
\text { (1050 and } 2100 \\
\text { min) }\end{array}$ & $\begin{array}{l}\text { INT 1: 2-year intervention } \\
\text { INT 2: 1-year intervention } \\
\text { Facilitator: } \\
\text { INT 1: Teachers } \\
\text { INT 2: Teachers }\end{array}$ & $\begin{array}{l}\text { INT 1+2: } 30 \text { min per week where } \\
\text { small-groups practiced manual } \\
\text { dexterity, gross motor skills, } \\
\text { graphomotor skills and cognitive } \\
\text { skills; teacher and occupation } \\
\text { therapist consultation and } \\
\text { monitoring }\end{array}$ & $\begin{array}{l}\text { The Beery-Buktenica } \\
\text { Developmental test of } \\
\text { Visual-Motor } \\
\text { integration, } 5^{\text {th }} \text { edition } \\
\text { (The Beery VMI); The } \\
\text { Movement Assessment } \\
\text { Battery of Children (M- } \\
\text { ABC), } 1^{\text {st }} \text { edition } \\
\text { Data Collection: } 0,1 \\
\text { and } 2 \text { y }\end{array}$ & $\begin{array}{l}\text { RET: } 27 / 28(96 \%) \text { for } \\
\text { VMI INT } 1,26 / 28 \\
(93 \%) \text { for MD INT 1; } \\
29 / 30(97 \%) \text { for VMI } \\
\text { and MD INT } 2 \\
\text { INT 1 = INT } 2\end{array}$ \\
\hline
\end{tabular}

\section{TABLE 2 Continued}




\begin{tabular}{|c|c|c|c|c|c|c|c|}
\hline $\begin{array}{l}\text { Reference (author, } \\
\text { year, country) }\end{array}$ & $\begin{array}{l}\text { Design and } \\
\text { Setting }\end{array}$ & Sample & $\begin{array}{l}\text { Intervention } \\
\text { Length (total min) }\end{array}$ & $\begin{array}{l}\text { Intervention Groups and } \\
\text { Facilitator }\end{array}$ & Intervention Content & $\begin{array}{l}\text { Fine Motor Measure } \\
\text { and data collection }\end{array}$ & Retention and Results \\
\hline $\begin{array}{l}\text { Hamilton et al } \\
\text { (2017) United } \\
\text { States }\end{array}$ & $\begin{array}{l}\text { RCT, pre- } \\
\text { kindergarten } \\
\text { program children }\end{array}$ & $\begin{array}{l}\text { INT: } n=74 \\
50 \% \text { girls; mean age } \\
54.32 \pm 3.07 \text { mo } \\
\text { CON: } n=75 \\
49.3 \% \text { girls; mean } \\
\text { age } 55.05 \pm 3.67 \text { mo }\end{array}$ & 16 wks $(800 \mathrm{~min})$ & $\begin{array}{l}\text { INT: Practical life activities } \\
\text { CON: Traditional kindergarten } \\
\text { curriculum } \\
\text { Facilitator: } \\
\text { INT: Teachers } \\
\text { CON: Teachers }\end{array}$ & $\begin{array}{l}\text { INT: } 50 \text { min per week where } 25 \\
\text { min gross motor and } 25 \text { min fine } \\
\text { motor } \\
\text { CON: play-based lessons also } 25 \\
\text { min in gymnasium and } 25 \text { min } \\
\text { classroom activities }\end{array}$ & $\begin{array}{l}\text { Peabody Developmental } \\
\text { Motor Scales, } 2^{\text {nd }} \\
\text { edition (PDMS-2) } \\
\text { Data collection: } 0,16 \\
\text { wks }\end{array}$ & $\begin{array}{l}\text { RET: Unclear } \\
\text { INT > CON: VM } \\
\text { subtest PDMS-2 }(\mathrm{p}<.01 ; \\
d=0.56) .\end{array}$ \\
\hline $\begin{array}{l}\text { Hartinger et al } \\
\text { (2016) Peru }\end{array}$ & $\begin{array}{l}\text { non-blinded } \\
\text { community } \\
\text { randomised trial, } \\
50 \text { rural } \\
\text { communities }\end{array}$ & $\begin{array}{l}\text { INT: } n=267 \\
49 \% \text { girls; mean age } \\
2.0 \pm 0.7 \mathrm{y} \\
\text { CON: } n=267 \\
47 \% \text { girls; mean age } \\
2.0 \pm 0.7 \mathrm{y} \\
\text { Overall aged } 6-35 \\
\text { mo }\end{array}$ & $\begin{array}{l}12 \operatorname{mo}(10950 \\
\min )\end{array}$ & $\begin{array}{l}\text { INT: Early Child Development } \\
\text { (ECD) intervention. } \\
\text { CON: Integrated Household } \\
\text { Intervention Package } \\
\text { Facilitator: } \\
\text { INT: Mothers } \\
\text { CON: N/A }\end{array}$ & $\begin{array}{l}\text { INT: } 30 \text { min a day by mothers, } 45 \\
\text { min training for mothers at baseline } \\
\text { and follow up training } 20-30 \mathrm{~min} \\
\text { per } 3 \text { weeks, every two months new } \\
\text { set of toys }\end{array}$ & $\begin{array}{l}\text { Lista de cotejo } \\
\text { (checklist) } \\
\text { Data collection: } 0,12 \\
\text { mo }\end{array}$ & $\begin{array}{l}\text { RET: } 435 / 534(81 \%) \\
\text { INT > CON: Proportion } \\
\text { indicators solved FM } \\
\text { increased for INT, not } \\
\text { in CON }\end{array}$ \\
\hline $\begin{array}{l}\text { Howe et al (2013) } \\
\text { United states }\end{array}$ & $\begin{array}{l}\text { non-equivalent } \\
\text { pretest-posttest } \\
\text { group, 1 } \\
\text { elementary school }\end{array}$ & $\begin{array}{l}\text { INT } 1: n=34 \\
\text { mean age } 6.69 \pm \\
0.42 \mathrm{y} \\
\text { INT } 2: n=38 \\
\text { mean age } 6.57 \pm \\
0.50 \mathrm{y}\end{array}$ & $\begin{array}{l}12 \text { wks ( } 480-540 \\
\text { min) }\end{array}$ & $\begin{array}{l}\text { INT 1: Intensive Practice Group } \\
\text { (IP) } \\
\text { INT 2: Visual-perceptual-motor } \\
\text { activity Group (VMP) } \\
\text { Facilitator: } \\
\text { INT 1 + 2: Occupational } \\
\text { Therapists }\end{array}$ & $\begin{array}{l}\text { INT } 1+2: 2 \text { times } 40-45 \text { min per } \\
\text { week: } 20 \text { min activities designed } \\
\text { by therapists, } 15 \text { min handwriting } \\
\text { activities and } 10 \text { handwriting games } \\
\text { (slightly different activities per } \\
\text { group) }\end{array}$ & $\begin{array}{l}\text { The Beery-Buktenica } \\
\text { Developmental test of } \\
\text { Visual-Motor } \\
\text { integration, } 5^{\text {th }} \text { edition } \\
\text { (The Beery VMI) } \\
\text { Data collection: } 0,12 \\
\text { wks }\end{array}$ & $\begin{array}{l}\text { RET: } 100 \% \\
\text { INT } 1=\text { INT } 2\end{array}$ \\
\hline $\begin{array}{l}\text { Janssens et al } \\
\text { (2013) Caribbean }\end{array}$ & $\begin{array}{l}\text { quasi-experiment, } \\
15 \text { communities }\end{array}$ & $\begin{array}{l}\text { INT: } n=229 \\
\text { CON: } n=232 \\
\text { At baseline, overall } \\
(n=389) 54 \% \\
\text { girls; mean age } 15.7 \\
\text { mo, aged } 1.1-38.1 \\
\text { mo }\end{array}$ & $\begin{array}{l}\text { Average length of } \\
\text { enrolment } 13.2 \\
\text { mo }(5130 \mathrm{~min})\end{array}$ & $\begin{array}{l}\text { INT: Roying Caregivers } \\
\text { Program } \\
\text { CON: Unclear } \\
\text { Facilitator: } \\
\text { INT: Rovers (trained personnel) } \\
\text { and caregivers. } \\
\text { CON: Unclear }\end{array}$ & $\begin{array}{l}\text { INT: } 2 \text { times } 45 \text { min per week: } \\
\text { Age-appropriate stimulation } \\
\text { activities through play, monthly } \\
\text { parenting meetings }\end{array}$ & $\begin{array}{l}\text { Mullen Scales of Early } \\
\text { Learning } \\
\text { Data Collection: } 0,13.2 \\
\text { mo average }\end{array}$ & $\begin{array}{l}\text { RET: Unclear } \\
\text { INT > CON: FM } \\
(\mathrm{p}<.05) \text { scale in the } \\
\text { youngest birth cohort } \\
\text { only }\end{array}$ \\
\hline
\end{tabular}

\begin{tabular}{|c|c|c|c|c|c|c|c|}
\hline $\begin{array}{l}\text { Reference (author, } \\
\text { year, country) }\end{array}$ & $\begin{array}{l}\text { Design and } \\
\text { Setting }\end{array}$ & Sample & $\begin{array}{l}\text { Intervention } \\
\text { Length (total min) }\end{array}$ & $\begin{array}{l}\text { Intervention Groups and } \\
\text { Facilitator }\end{array}$ & Intervention Content & $\begin{array}{l}\text { Fine Motor Measure } \\
\text { and data collection }\end{array}$ & Retention and Results \\
\hline
\end{tabular}




\begin{tabular}{|c|c|c|c|c|c|c|c|}
\hline $\begin{array}{l}\text { Jeon et al (2016) } \\
\text { South Korea }\end{array}$ & RCT & $\begin{array}{l}\text { INT: } n=57 \\
35.1 \% \text { girls } \\
\text { CON: } n=60 \\
38.3 \% \text { girls } \\
\text { Overall aged } 4-6 y\end{array}$ & 6 mo (unclear) & $\begin{array}{l}\text { INT: Self-Imagery Training } \\
\text { (SIT) program. } \\
\text { CON: N/A. } \\
\text { Facilitator: } \\
\text { INT: Researchers } \\
\text { CON: N/A }\end{array}$ & $\begin{array}{l}\text { INT: } 48 \text { sessions of drawing images } \\
\text { in their minds }\end{array}$ & $\begin{array}{l}\text { Korean Developmental } \\
\text { Test of Visual } \\
\text { Perception, } 2^{\text {nd }} \text { edition } \\
\text { (K-DTVP-2) } \\
\begin{array}{l}\text { Data Collection: } 0,6 \\
\text { mo }\end{array}\end{array}$ & $\begin{array}{l}\text { RET: } 100 \% \\
\text { INT > CON: VMI } \\
(\mathrm{p}<.001) ; \mathrm{VP}(\mathrm{p}<.001)\end{array}$ \\
\hline $\begin{array}{l}\text { Lahav et al (2008) } \\
\text { Israel }\end{array}$ & $\begin{array}{l}\text { RCT, } 7 \text { schools } \\
\text { and } 8 \\
\text { kindergartens }\end{array}$ & $\begin{array}{l}\text { INT } 1: n=53 \\
\text { INT } 2: n=63 \\
\text { CON: } n=52 \\
\text { Overall: } \\
49 \% \text { girls; mean age } \\
71.08 \text { mo, aged } 56- \\
90 \text { mo }\end{array}$ & 12 wks (540 min) & $\begin{array}{l}\text { INT 1: Directive Visual Motor } \\
\text { intervention (DVMI) } \\
\text { INT 2: Nondirective Supportive } \\
\text { intervention (NDSI) } \\
\text { CON: no treatment } \\
\text { Facilitator: } \\
\text { INT 1: Occupational Therapy } \\
\text { Students } \\
\text { INT 2: Occupational Therapy } \\
\text { Students } \\
\text { CON: N/A }\end{array}$ & $\begin{array}{l}\text { INT 1: } 45 \text { min per week of fine } \\
\text { motor activities, paper work and } \\
\text { patterns use } \\
\text { INT 2: } 45 \text { min per week of mind } \\
\text { games, games of chance social } \\
\text { games, memory games, cards and } \\
\text { boards games (goal-directed } \\
\text { activities) }\end{array}$ & $\begin{array}{l}\text { The Beery-Buktenica } \\
\text { Developmental test of } \\
\text { Visual-Motor } \\
\text { integration, } 4^{\text {th }} \text { edition } \\
\text { (The Beery VMI); } \\
\text { Developmental Test of } \\
\text { Visual Perception, } 2^{\text {nd }} \\
\text { edition (DTVP-2) } \\
\text { Data Collection: 0, } 12 \\
\text { wks }\end{array}$ & $\begin{array}{l}\text { RET: } 167 / 168(99 \%) \\
\text { for VMI } \\
\text { INT } 1>\text { CON: VMI for } \\
\text { first graders }(\mathrm{p}<.05) \\
\text { INT } 2>\text { INT } 1: \text { VMI for } \\
\text { kindergarten children } \\
(\mathrm{p}<.05) \\
\text { INT } 2>\text { CON: VMI for } \\
\text { kindergarten children } \\
(\mathrm{p}<.01)\end{array}$ \\
\hline $\begin{array}{l}\text { Lin et al (2017) } \\
\text { Taiwan }\end{array}$ & $\begin{array}{l}\text { Quasi-experiment, } \\
\text { home based }\end{array}$ & $\begin{array}{l}\text { INT } 1: n=40 \\
\text { INT } 2: n=40 \\
\text { Overall } 35 \% \text { girls; } \\
\text { mean age } 61.0 \pm 7.6 \\
\text { mo }\end{array}$ & $\begin{array}{l}24 \text { wks }(3300 \\
\min )\end{array}$ & $\begin{array}{l}\text { INT 1: Touch-screen-tablet } \\
\text { group } \\
\text { INT 2: Non-touch-screen-tablet } \\
\text { group } \\
\text { Facilitator: } \\
\text { INT 1 + 2: Parents }\end{array}$ & $\begin{array}{l}\text { INT 1: } 20 \text { min a day of iPad apps, } \\
24 \text { different age appropriate apps } \\
\text { designed to develop fine motor } \\
\text { skills } \\
\text { INT } 2: 20 \text { min a day of typically } \\
\text { age-appropriate fine motor skill } \\
\text { activities }\end{array}$ & $\begin{array}{l}\text { Bruininks-Oseretsky } \\
\text { Test of Motor } \\
\text { Proficiency, } 2^{\text {nd }} \text { edition } \\
\text { (BOT-2) } \\
\text { Data collection: } 0,24 \\
\text { wks }\end{array}$ & $\begin{array}{l}\text { RET: } 100 \% \\
\text { INT } 1<\text { INT } 2: \text { FM } \\
\text { precision }(p<.001) ; \text { FM } \\
\text { integration }(p=.008) \\
\operatorname{MD~}(p=.003)\end{array}$ \\
\hline $\begin{array}{l}\text { Lust et al (2011) } \\
\text { United States }\end{array}$ & $\begin{array}{l}\text { Quasi-experiment, } \\
1 \text { preschool }\end{array}$ & $\begin{array}{l}\text { INT: } n=20 \\
45 \% \text { girls; mean age } \\
55.4 \pm 3.74 \text { mo } \\
\text { CON: } n=20 \\
25 \% \text { girls; mean age } \\
55.9 \pm 3.48 \text { mo } \\
\text { Overall aged } 4 \text { to } \\
4.92 \text { y }\end{array}$ & 6 mo (940 min) & $\begin{array}{l}\text { INT: Handwriting Without } \\
\text { Tears - Get Set for School } \\
\text { (HWT-GSS) } \\
\text { CON: Standard Head Start } \\
\text { Curriculum } \\
\text { Facilitator: } \\
\text { INT: Occupational Therapy } \\
\text { students, authors and teachers } \\
\text { CON: Unclear }\end{array}$ & $\begin{array}{l}\text { INT: } 3 \text { times } 20 \text { min per week (total } \\
\text { of } 47 \text { sessions) of } 5 \text { min warm up } \\
\text { and } 15 \text { min small group activities } \\
\text { including body awareness skills, } \\
\text { directional concepts, and letter-play } \\
\text { activities and progressed to } \\
\text { colouring and tracing of capital } \\
\text { letters and shapes }\end{array}$ & $\begin{array}{l}\text { Bruininks-Oseretsky } \\
\text { Test of Motor } \\
\text { Proficiency, } 2^{\text {nd }} \text { edition } \\
\text { (BOT-2) } \\
\begin{array}{l}\text { Data Collection: } 0,6 \\
\text { mo }\end{array}\end{array}$ & $\begin{array}{l}\text { RET: } 32 / 40(80 \%) \\
\text { INT > CON: FM } \\
\text { precision }(\mathrm{p}=.045 ; \\
d=0.74) ; \text { FM integration } \\
(\mathrm{p}=.021 ; d=0.87)\end{array}$ \\
\hline \multicolumn{8}{|c|}{ TABLE 2 Continued } \\
\hline $\begin{array}{l}\text { Reference (author, } \\
\text { year, country) }\end{array}$ & $\begin{array}{l}\text { Design and } \\
\text { Setting }\end{array}$ & Sample & $\begin{array}{l}\text { Intervention } \\
\text { Length (total min) }\end{array}$ & $\begin{array}{l}\text { Intervention Groups and } \\
\text { Facilitator }\end{array}$ & Intervention Content & $\begin{array}{l}\text { Fine Motor Measure } \\
\text { and data collection }\end{array}$ & Retention and Results \\
\hline
\end{tabular}




\begin{tabular}{|c|c|c|c|c|c|c|c|}
\hline $\begin{array}{l}\text { McCormick et al } \\
\text { (1971) }\end{array}$ & $\begin{array}{l}\text { Quasi-experiment, } \\
1 \text { Montessori } \\
\text { preschool }\end{array}$ & $\begin{array}{l}\text { INT: } n=25 \\
36.0 \% \text { girls; mean } \\
\text { age } 4.4 \mathrm{y} \text {, aged } 3.3 \\
\text { to } 5.8 \mathrm{y} \\
\text { CON: } n=24 \\
58.3 \% \text { girls; mean } \\
\text { age } 4.3 \mathrm{y} \text {, aged } 2.9 \\
\text { to } 5.7 \mathrm{y}\end{array}$ & $7 \mathrm{mo}(2700 \mathrm{~min})$ & $\begin{array}{l}\text { INT: Perceptual-motor Training } \\
\text { CON: Regular Montessori } \\
\text { Training } \\
\text { Facilitator: } \\
\text { INT: Unclear } \\
\text { CON: Unclear }\end{array}$ & $\begin{array}{l}\text { INT: } 3 \text { times } 30 \text { min per week of } \\
\text { gross- and fine motor exercises }\end{array}$ & $\begin{array}{l}\text { Visual-motor sequential } \\
\text { subtest of the ITPA } \\
\text { Data collection: } 0,7 \\
\text { months }\end{array}$ & $\begin{array}{l}\text { RET: } 100 \% \\
\text { INT > CON: VM } \\
(p<.05)\end{array}$ \\
\hline $\begin{array}{l}\text { Ohl et al (2013) } \\
\text { United States }\end{array}$ & $\begin{array}{l}\text { pretest-posttest } \\
\text { control-group } \\
\text { design; RCT, } 6 \\
\text { elementary } \\
\text { schools }\end{array}$ & $\begin{array}{l}\text { a INT: } n=47 \\
42.6 \% \text { girls; mean } \\
\text { age } 5.18 \pm 0.35 \mathrm{y} \\
\text { CON: } n=28 \\
\text { 46.4\% girls; mean } \\
\text { age } 5.20 \pm 0.34 \mathrm{y}\end{array}$ & $\begin{array}{l}10 \text { wks }(300 \mathrm{~min} \\
\text { lessons, } 573 \mathrm{~min} \\
\text { consultation) }\end{array}$ & $\begin{array}{l}\text { INT: Specialized Teaching and } \\
\text { Enhancement of Performance } \\
\text { Skills for Kindergarteners } \\
\text { (STEPS-K) } \\
\text { CON: Unclear } \\
\text { Facilitator: } \\
\text { INT: Occupational Therapists } \\
\text { and teachers } \\
\text { CON: Unclear }\end{array}$ & $\begin{array}{l}\text { INT: } 10 \text { times } 30 \text { min lessons, a } \\
\text { classroom fine motor center with } \\
\text { new activities and consultation } \\
\text { between OT and teacher }\end{array}$ & $\begin{array}{l}\text { Bruininks-Oseretsky } \\
\text { Test of Motor } \\
\text { Proficiency, } 2^{\text {nd }} \text { edition } \\
\text { (BOT-2); The Beery- } \\
\text { Buktenica } \\
\text { Developmental test of } \\
\text { Visual-Motor } \\
\text { integration, } 5^{\text {th }} \text { edition } \\
\text { (The Beery VMI) } \\
\\
\text { Data Collection: } 0,10 \\
\text { wks }\end{array}$ & $\begin{array}{l}\text { RET: } 75 / 113(66 \%) \\
\text { INT > CON: VMI } \\
(\mathrm{p}=.009 ; d=-0.34) ; \text { FM } \\
(\mathrm{p}=.023 ; d=-0.24)\end{array}$ \\
\hline \multirow[t]{2}{*}{$\begin{array}{l}\text { Pfeiffer et al (2015) } \\
\text { United States }\end{array}$} & \multirow[t]{2}{*}{$\begin{array}{l}\text { two-group pretest- } \\
\text { posttest; RCT, } 2 \\
\text { public schools }\end{array}$} & $\begin{array}{l}\text { Kindergarteners } \\
\text { only } \\
\text { INT: } n=29 \\
\text { CON: } n=27\end{array}$ & 8 wks (800 min) & $\begin{array}{l}\text { INT: Size Matters Handwriting } \\
\text { Program (SMHP) } \\
\text { CON: Usual handwriting } \\
\text { instructions }\end{array}$ & $\begin{array}{l}\text { INT: } 40 \text { times } 20 \text { min intervention } \\
\text { CON: usual handwriting } \\
\text { instructions }\end{array}$ & $\begin{array}{l}\text { The Beery-Buktenica } \\
\text { Developmental test of } \\
\text { Visual-Motor } \\
\text { integration, } 6^{\text {th }} \text { edition } \\
\text { (The Beery VMI) }\end{array}$ & $\begin{array}{l}\text { RET: Unclear } \\
\text { INT }=\text { CON }\end{array}$ \\
\hline & & $\begin{array}{l}\text { Overall } 58.2 \% \text { girls; } \\
\text { aged } 5-6 \mathrm{y}\end{array}$ & & $\begin{array}{l}\text { Facilitator: } \\
\text { INT: Teachers } \\
\text { CON: Teachers }\end{array}$ & & $\begin{array}{l}\text { Data Collection: } 0,8 \\
\text { wks }\end{array}$ & \\
\hline
\end{tabular}

\begin{tabular}{|c|c|c|c|c|c|c|c|}
\hline $\begin{array}{l}\text { Reference (author, } \\
\text { year, country) }\end{array}$ & $\begin{array}{l}\text { Design and } \\
\text { Setting }\end{array}$ & Sample & $\begin{array}{l}\text { Intervention } \\
\text { Length (total min) }\end{array}$ & $\begin{array}{l}\text { Intervention Groups and } \\
\text { Facilitator }\end{array}$ & Intervention Content & $\begin{array}{l}\text { Fine Motor Measure } \\
\text { and data collection }\end{array}$ & Retention and Results \\
\hline
\end{tabular}




\begin{tabular}{lll}
\hline Piek et al (2014) & nested cohort; & Overall: \\
Australia & RCT, 12 schools & $N=511(50 \%$ \\
& & girls); Mean age \\
& & $5.42 \pm 0.30 \mathrm{y}$, aged \\
& & $4.83-6.17 \mathrm{y}$
\end{tabular}

Pienaar et al (2011) Quasi-experiment,

South Africa

8 pre-primary
schools

INT: $\mathrm{n}=20$

$46 \%$ girls; aged 4

$6 \mathrm{y}$

CON: $\mathrm{n}=20$

$63 \%$ girls; aged 4 -

$5 \mathrm{y}$

$\begin{array}{ll}\text { Ratzon et al (2007) } & \text { RCT, } 4 \\ \text { Israel } & \text { elementary } \\ \text { schools }\end{array}$

a INT: $n=24$

$45.8 \%$ girls; mean

age $80 \pm 4$ mo, aged

10 wks $(1200$
$\min )$

7 months (1800 INT: The perceptual-motor

min) development programme

$72-88 \mathrm{mo}$

CON: $n=28$

$57.1 \%$ girls; mean

age $79 \pm 4 \mathrm{mo}$, aged

$73-89$ mo
INT: Animal Fun Program

CON: normal curriculum

Facilitator:

INT: Teachers

CON: Teachers

CON: attending nursery schools

INT: 1 hour a week; 40 min of structured gross and fine motor (3-5

$\mathrm{min}$ ) activities and $20 \mathrm{~min}$ free play.

The fine motor skills include

Facilitator:

INT: Trained professionals

(Kinderkineticists)

CON: unclear

INT: 4 times 30 min a week of

social/emotional activities

with clay, pinching washing peg

around the edges of a frisbee,

flicking fingers in the air and

placing shapes in the correct holes on a board

INT: 45 min once a week of playful fine-motor activities and penciland-paper activities

CON: No Treatment

Facilitator:

INT: Occupational Therapy

students

CON: N/A
Test of Motor

Proficiency, $2^{\text {nd }}$ edition

(BOT-2), The

Movement Assessment

Battery of Children, $2^{\text {nd }}$

edition (M-ABC-2)

Data Collection: 0,6

and 12 mo

Peabody Developmental

Motor Scales, $2^{\text {nd }}$

edition (PDMS-2)

Data collection: 0, 7 mo

$d=0.929$ )

Bruininks-Oseretsky

Test of Motor

Proficiency (BOT-2);

The Beery-Buktenica

Developmental test of

Visual-Motor

integration, $4^{\text {th }}$ edition

(The Beery VMI);

Developmental Test of

Visual Perception

(DTVP-2)

Data Collection: 0, 12

wks

f

RET: 450/511 (88\%) at

post-test, 355/511

(66\%) at follow up

INT > CON: FM

$(p=.035)$ with INT

significant improvement

pre-to follow-up

$(\mathrm{p}=.001)$. Boys $>$ Girls:

$\mathrm{FM}(\mathrm{p}=.022)$

RET: $32 / 40$ (80\%)

INT > CON: FM

$(\mathrm{p}=0.033, \mathrm{~d}=0.832)$

INT $>$ : VM $(\mathrm{p}=0.023$,

RET: 52/59 (92\%)

$39 / 52(75 \%)$ for BOT-2

INT > CON: DTVP-2

$(\mathrm{p}=.001) ; \mathrm{BOT}-2$

$(\mathrm{p}=.000)$ 


\begin{tabular}{|c|c|c|c|c|c|c|c|}
\hline $\begin{array}{l}\text { Ratzon et al (2009) } \\
\text { Israel, A }\end{array}$ & $\begin{array}{l}\text { RCT, } 10 \text { classes } \\
\text { from } 4 \text { elementary } \\
\text { schools }\end{array}$ & $\begin{array}{l}\text { INT } 1: n=28 \\
46.2 \% \text { girls } \\
\text { INT } 2: n=26 \\
50.0 \% \text { girls } \\
\\
\text { Overall mean age } \\
6.06 \pm 4.3 \mathrm{y}\end{array}$ & 12 wks (unclear) & $\begin{array}{l}\text { INT 1: Collaborative- } \\
\text { consultation treatment group } \\
\text { with HPP } \\
\text { INT 2: Collaborative- } \\
\text { consultation treatment group } \\
\text { Facilitator: } \\
\text { INT 1 + 2: Teachers, parents, } \\
\text { Occupational Therapists and } \\
\text { social workers }\end{array}$ & $\begin{array}{l}\text { INT 1: Consultation once a week } \\
\text { and an activity home kit for parents } \\
\text { once every four weeks } \\
\text { INT 2: Consultation once a week }\end{array}$ & $\begin{array}{l}\text { The Beery-Buktenica } \\
\text { Developmental test of } \\
\text { Visual-Motor } \\
\text { integration, } 4^{\text {th }} \text { edition } \\
\text { (The Beery VMI); } \\
\text { Developmental Test of } \\
\text { Visual Perception } \\
\text { (DTVP-2) } \\
\text { Data collection: } 0,12 \\
\text { wks }\end{array}$ & $\begin{array}{l}\text { RET: } 45 / 54(83.3 \%) \\
\text { INT }=\text { CON }\end{array}$ \\
\hline $\begin{array}{l}\text { Ratzon et al (2009) } \\
\text { Israel, B }\end{array}$ & $\begin{array}{l}\text { RCT, } 6 \\
\text { elementary } \\
\text { schools }\end{array}$ & $\begin{array}{l}\text { INT } 1: n=29 \\
\text { INT } 2: n=38 \\
\text { INT 3: } n=24 \\
\text { CON: } n=56 \\
\text { Overall } 50.0 \% \text { girls; } \\
\text { mean age } 76.63 \pm \\
4.03 \text { mo }\end{array}$ & 12 wks (unclear) & $\begin{array}{l}\text { INT1: Direct Treatment (DT) } \\
\text { INT2: Collaborative- } \\
\text { Consultation Treatment (CC) } \\
\text { INT3: Combined Treatment } \\
\text { (CT) } \\
\text { CON: No treatment } \\
\text { Facilitator: } \\
\text { INT1: Occupational Therapy } \\
\text { students. } \\
\text { INT2: Teachers and } \\
\text { Occupational Therapists } \\
\text { INT3: INT1 + INT2 }\end{array}$ & $\begin{array}{l}\text { INT1: once a week for } 45 \text { min of } \\
\text { playful fine-motor activities and } \\
\text { pencil-and-paper activities } \\
\text { INT2: consultation once a week } \\
\text { INT3: } 45 \text { min INT } 1 \text { plus another } \\
15 \text { min treatment and consultation }\end{array}$ & $\begin{array}{l}\text { The Beery-Buktenica } \\
\text { Developmental test of } \\
\text { Visual-Motor } \\
\text { integration, } 4^{\text {th }} \text { edition } \\
\text { (The Beery VMI); } \\
\text { Developmental Test of } \\
\text { Visual Perception, } 2^{\text {nd }} \\
\text { edition (DTVP-2) } \\
\text { Data collection: } 1,12 \\
\text { wks }\end{array}$ & $\begin{array}{l}\text { RET: Unclear } \\
\text { INT > CON: DTVP-2 } \\
(\mathrm{p}<.001)\end{array}$ \\
\hline $\begin{array}{l}\text { Tzuriel et al (1992) } \\
\text { Israel }\end{array}$ & $\begin{array}{l}\text { pre-test post-test } \\
\text { design; RCT, } 4 \\
\text { kindergartens }\end{array}$ & $\begin{array}{l}\text { INT: } n=30 \\
\text { CON: } n=30 \\
\text { Overall aged } 5.6- \\
6.0 \mathrm{y}\end{array}$ & $5 \mathrm{mo}(1320 \mathrm{~min})$ & $\begin{array}{l}\text { INT: Structured program of } \\
\text { visual-motor integration (SP- } \\
\text { VMI) } \\
\text { CON: Free play activities } \\
\text { Facilitator: } \\
\text { INT: Teachers } \\
\text { CON: Teachers }\end{array}$ & $\begin{array}{l}\text { INT: } 2 \text { times } 30 \text { min a week of } \\
\text { copying and drawing activities }\end{array}$ & $\begin{array}{l}\text { The Beery-Buktenica } \\
\text { Developmental test of } \\
\text { Visual-Motor } \\
\text { integration, unknown } \\
\text { edition (The Beery } \\
\text { VMI) } \\
\text { Data Collection: } 0,5 \\
\text { mo }\end{array}$ & $\begin{array}{l}\text { RET: Unclear } \\
\text { INT > CON: INT } \\
\text { improved much more } \\
\text { on VMI. Significance } \\
\text { for disadvantaged group } \\
\text { only not given. }\end{array}$ \\
\hline \multicolumn{8}{|c|}{ TABLE 2 Continued } \\
\hline $\begin{array}{l}\text { Reference (author, } \\
\text { year, country) }\end{array}$ & $\begin{array}{l}\text { Design and } \\
\text { Setting }\end{array}$ & Sample & $\begin{array}{l}\text { Intervention } \\
\text { Length (total min) }\end{array}$ & $\begin{array}{l}\text { Intervention Groups and } \\
\text { Facilitator }\end{array}$ & Intervention Content & $\begin{array}{l}\text { Fine Motor Measure } \\
\text { and data collection }\end{array}$ & Retention and Results \\
\hline
\end{tabular}


Ulutas et al (2016)

Turkey

pretest-posttest

permanence test

control group

design, RCT,

home based

INT: $n=22$

$54.5 \%$ girls

CON: $n=22$

$50.0 \%$ girls

Overall aged $9-12$

mo

$\begin{array}{ll}\text { Zoghi et al (2015) Quasi-experiment } & \text { INT } 1: n=16 \\ \text { Iran } & \text { CON } 1: n=15 \\ & \text { CON } 2: n=15\end{array}$

Overall 48\% girls

mean age $=34 \mathrm{mo}$
12 wks (540 min) INT: Home-centered MotherInfant Interaction Program

CON: No treatment

Facilitator:

INT: Parents, researchers

CON: N/A

INT: Enriched Motor

Affordance Intervention

environment

CON1: attending daycare

CON2: Not attending daycare

Facilitator:

INT: Unclear
INT: once a week for $45 \mathrm{~min}$ of activities to improve interaction mother / infant including game activities promoting infant's

cognitive, language, social,

emotional, fine motor and gross motor

INT: 36 sessions in an enriched motor affordance environment
Denver Developmenta Screening Test, $2^{\text {nd }}$ edition (DDST II)

Data Collection: 0, 12 and $15 \mathrm{wks}$

Denver Developmental

Screening Test, $2^{\text {nd }}$

edition (DDST II)

Data collection: $0,3 \mathrm{mo}$
RET: Unclear INT > CON: FM subdimension pre- post

$$
(\mathrm{p}=.001)
$$

INT decrease follow up $(\mathrm{p}=.004)$

RET: Unclear INT > CON: FM $(\mathrm{p}=.017 ; d=0.14)$

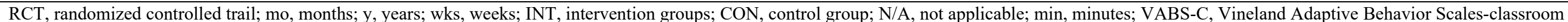

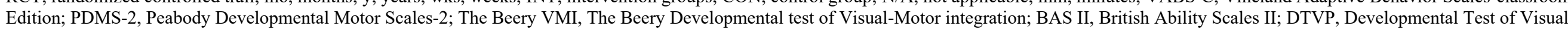

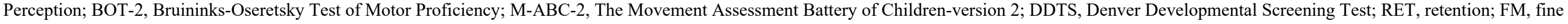
motor skills; VMI, visual-motor integration skills; VP, visual perception; MD, manual dexterity; VM, visual-motor; MC, motor coordination

${ }^{a}$ Sample information only available after retention 


\section{Supplemental Digital Content 2}

\begin{tabular}{|c|c|c|c|c|c|c|c|c|c|}
\hline Study & $\begin{array}{c}\text { Baseline } \\
\text { characteristics } \\
\text { by group }\end{array}$ & $\begin{array}{l}\text { Randomization } \\
\text { described and } \\
\text { completed }\end{array}$ & $\begin{array}{l}\text { Valid } \\
\text { Measure of } \\
\text { FMS }\end{array}$ & $\begin{array}{l}\text { Assessor } \\
\text { Blinding }\end{array}$ & $\begin{array}{c}\text { Drop out a } \leq 20 \% \\
\text { for }<6 \text {-months and } \\
30 \% \text { for } \geq 6 \text {-months }\end{array}$ & $\begin{array}{c}\text { Power } \\
\text { calculation }\end{array}$ & $\begin{array}{l}\text { Intention to } \\
\text { treat for FMS } \\
\text { outcomes }\end{array}$ & $\begin{array}{l}\text { Covariates } \\
\text { Accounted for } \\
\text { in Analyses }\end{array}$ & $\begin{array}{c}\text { Summary Results Presented } \\
\text { / Estimated Effect Size }+ \\
\text { precision estimation }\end{array}$ \\
\hline Axford et al (2018) & $\mathrm{Y}$ & $\mathrm{N}$ & Y & Y & $\mathrm{Y}$ & $\mathrm{N}$ & $?$ & $\mathrm{~N}$ & $\mathrm{Y}$ \\
\hline Bayona et al (2006) & $\mathrm{Y}$ & N/A & $\mathrm{Y}$ & $\mathrm{N}$ & $\mathrm{N}$ & $\mathrm{N}$ & N/A & $\mathrm{N}$ & Y \\
\hline Bazyk et al (2009) & $\mathrm{N}$ & N/A & $\mathrm{Y}$ & $\mathrm{N}$ & $\mathrm{N}$ & $\mathrm{N}$ & $?$ & $\mathrm{~N}$ & $\mathrm{Y}$ \\
\hline Bhatia et al (2015) & Y & $\mathrm{N}$ & $?$ & $\mathrm{~N}$ & $\mathrm{~N}$ & $\mathrm{~N}$ & $?$ & Y & $\mathrm{Y}$ \\
\hline Brown (2010) & $\mathrm{Y}$ & $\mathrm{Y}$ & $\mathrm{Y}$ & $\mathrm{N}$ & $\mathrm{N}$ & $\mathrm{N}$ & $?$ & $\mathrm{Y}$ & $\mathrm{Y}$ \\
\hline Case- Smith (2000) & $\mathrm{Y}$ & N/A & $\mathrm{Y}$ & N/A & $\mathrm{Y}$ & $\mathrm{N}$ & N/A & $\mathrm{N}$ & Y \\
\hline Dankert et al (2003) & $\mathrm{N}$ & $\mathrm{Y}$ & $\mathrm{Y}$ & $?$ & $\mathrm{Y}$ & $\mathrm{N}$ & $\mathrm{N}$ & $\mathrm{Y}$ & $\mathrm{Y}$ \\
\hline Dibek (2012) & $\mathrm{Y}$ & $\mathrm{N}$ & $\mathrm{Y}$ & $\mathrm{N}$ & $\mathrm{Y}$ & $\mathrm{N}$ & $\mathrm{N}$ & $\mathrm{N}$ & $\mathrm{N}$ \\
\hline Erasmus et al (2015) & $\mathrm{Y}$ & $\mathrm{N}$ & $\mathrm{Y}$ & $\mathrm{N}$ & $\mathrm{N}$ & $\mathrm{N}$ & $?$ & $\mathrm{Y}$ & $\mathrm{Y}$ \\
\hline Gabbard (1978) & $\mathrm{N}$ & $\mathrm{Y}$ & $?$ & $\mathrm{Y}$ & $\mathrm{N}$ & $\mathrm{N}$ & $?$ & $\mathrm{Y}$ & $?$ \\
\hline Golos et al (2011) & $\mathrm{Y}$ & $\mathrm{Y}$ & $\mathrm{Y}$ & $\mathrm{Y}$ & $?$ & $\mathrm{Y}$ & $\mathrm{N}$ & $\mathrm{N}$ & $\mathrm{Y}$ \\
\hline Golos et al (2013) & $\mathrm{N}$ & $\mathrm{N}$ & $\mathrm{Y}$ & $\mathrm{Y}$ & $\mathrm{N}$ & $\mathrm{Y}$ & $\mathrm{N}$ & $\mathrm{Y}$ & $\mathrm{Y}$ \\
\hline Hamilton et al (2017) & $\mathrm{N}$ & Y & Y & $\mathrm{N}$ & $\mathrm{N}$ & $\mathrm{N}$ & ? & Y & $\mathrm{Y}$ \\
\hline Hartinger et al (2016) & $\mathrm{Y}$ & $\mathrm{Y}$ & Y & $\mathrm{N}$ & $\mathrm{Y}$ & $\mathrm{N}$ & $\mathrm{N}$ & $\mathrm{N}$ & $\mathrm{N}$ \\
\hline Howe et al (2013) & $\mathrm{Y}$ & $\mathrm{N}$ & $\mathrm{Y}$ & $\mathrm{Y}$ & $\mathrm{N}$ & $\mathrm{N}$ & $?$ & $\mathrm{~N}$ & $\mathrm{Y}$ \\
\hline Janssens et al (2013) & $\mathrm{Y}$ & $\mathrm{N}$ & Y & $\mathrm{N}$ & $\mathrm{N}$ & $\mathrm{N}$ & $\mathrm{Y}$ & Y & $\mathrm{Y}$ \\
\hline Jeon et al (2016) & $\mathrm{Y}$ & $\mathrm{Y}$ & $\mathrm{Y}$ & $\mathrm{N}$ & $\mathrm{N}$ & $\mathrm{N}$ & $?$ & $\mathrm{~N}$ & $\mathrm{~N}$ \\
\hline Lahav et al (2008) & $\mathrm{N}$ & $\mathrm{Y}$ & $\mathrm{Y}$ & Y & $\mathrm{N}$ & $\mathrm{N}$ & $\mathrm{N}$ & $\mathrm{Y}$ & $\mathrm{Y}$ \\
\hline Lin et al (2017) & $\mathrm{Y}$ & $\mathrm{N}$ & $\mathrm{Y}$ & $\mathrm{Y}$ & $\mathrm{Y}$ & $\mathrm{Y}$ & $?$ & $\mathrm{Y}$ & $\mathrm{Y}$ \\
\hline Lust et al (2011) & $\mathrm{Y}$ & $\mathrm{N}$ & $\mathrm{Y}$ & $\mathrm{N}$ & $\mathrm{Y}$ & $\mathrm{Y}$ & $\mathrm{N}$ & $\mathrm{N}$ & $\mathrm{Y}$ \\
\hline McCormick et al (1971) & $\mathrm{Y}$ & $\mathrm{N}$ & $\mathrm{Y}$ & $\mathrm{N}$ & $\mathrm{N}$ & $\mathrm{N}$ & $?$ & $\mathrm{~N}$ & $\mathrm{Y}$ \\
\hline Ohl et al (2013) & $\mathrm{Y}$ & $\mathrm{Y}$ & $\mathrm{Y}$ & $\mathrm{Y}$ & $\mathrm{N}$ & $\mathrm{N}$ & $?$ & $\mathrm{~N}$ & $\mathrm{Y}$ \\
\hline Pfeiffer et al (2015) & $\mathrm{Y}$ & $\mathrm{Y}$ & Y & $\mathrm{Y}$ & $?$ & $\mathrm{~N}$ & $\mathrm{~N}$ & $\mathrm{~N}$ & $\mathrm{~N}$ \\
\hline Piek et al (2014) & $\mathrm{Y}$ & $\mathrm{Y}$ & $\mathrm{Y}$ & $\mathrm{N}$ & $\mathrm{N}$ & $\mathrm{N}$ & $\mathrm{N}$ & $\mathrm{Y}$ & $\mathrm{Y}$ \\
\hline Pienaar et al (2011) & $\mathrm{Y}$ & $\mathrm{N}$ & $\mathrm{Y}$ & $\mathrm{N}$ & $\mathrm{Y}$ & $\mathrm{N}$ & $\mathrm{N}$ & $\mathrm{Y}$ & $\mathrm{Y}$ \\
\hline Ratzon et al (2007) & $\mathrm{Y}$ & $\mathrm{Y}$ & $\mathrm{Y}$ & $\mathrm{N}$ & $\mathrm{Y}$ & $\mathrm{N}$ & $\mathrm{N}$ & $\mathrm{Y}$ & $\mathrm{Y}$ \\
\hline Ratzon et al (2009) A & $\mathrm{Y}$ & $\mathrm{Y}$ & $\mathrm{Y}$ & $\mathrm{N}$ & $\mathrm{Y}$ & $\mathrm{N}$ & $\mathrm{N}$ & $\mathrm{Y}$ & $\mathrm{Y}$ \\
\hline Ratzon et al (2009) B & $\mathrm{Y}$ & $\mathrm{Y}$ & $\mathrm{Y}$ & $\mathrm{N}$ & $?$ & $\mathrm{~N}$ & $\mathrm{~N}$ & $\mathrm{Y}$ & $\mathrm{Y}$ \\
\hline Tzuriel et al (1992) & $\mathrm{N}$ & $\mathrm{Y}$ & $\mathrm{Y}$ & $\mathrm{N}$ & $\mathrm{N}$ & $\mathrm{N}$ & $\mathrm{N}$ & $\mathrm{N}$ & $\mathrm{N}$ \\
\hline Ulutas et al (2016) & $\mathrm{Y}$ & $\mathrm{Y}$ & $\mathrm{Y}$ & $\mathrm{N}$ & $?$ & $\mathrm{~N}$ & $?$ & $\mathrm{~N}$ & $\mathrm{Y}$ \\
\hline Zoghi et al (2015) & $\mathrm{N}$ & $?$ & $\mathrm{Y}$ & $\mathrm{N}$ & $?$ & $\mathrm{Y}$ & $?$ & $\mathrm{Y}$ & $\mathrm{N}$ \\
\hline
\end{tabular}

FMS, fine motor skills; Y, explicitly described and present; N, absent; ?, unclear or inadequately described; N/A, not applicable because of study design 


\section{Supplemental Digital Content 3}

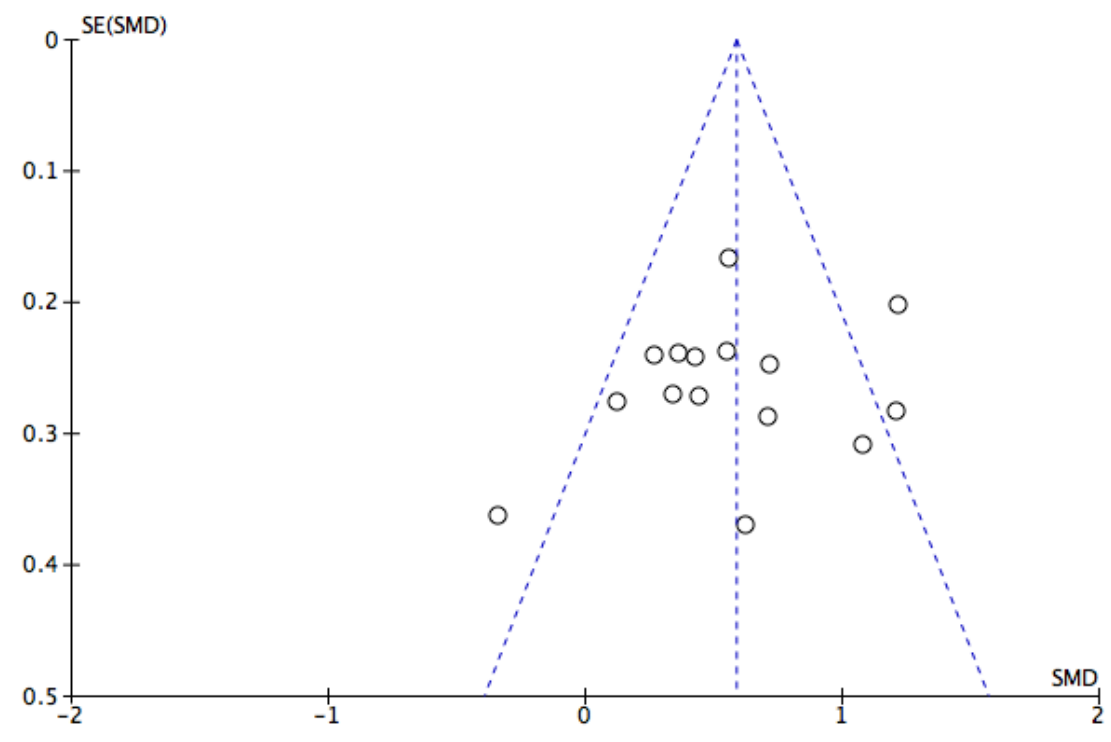

FIGURE 6 Funnel plot indication publication bias for Visual Motor outcome (Visual Motor, Visual Motor Skills \& Visual Motor Integration). 